\title{
Prognostic Biomarkers in Ovarian Cancer
}

Jie Huang ${ }^{1}$, Wei Hu${ }^{1}$, and Anil K Sood ${ }^{1,2,3,4}$

${ }^{1}$ Department of Gynecologic Oncology and Reproductive Medicine, The University of Texas M. D. Anderson Cancer Center, Houston, TX

${ }^{2}$ Department of Cancer Biology, The University of Texas M. D. Anderson Cancer Center, Houston, TX

${ }^{3}$ Center for RNAi and non-coding RNA, The University of Texas M. D. Anderson Cancer Center, Houston, TX

\section{Abstract}

Epithelial ovarian cancer (EOC) remains the most lethal gynecological malignancy despite several decades of progress in diagnosis and treatment. Taking advantage of the robust development of discovery and utility of prognostic biomarkers, clinicians and researchers are developing personalized and targeted treatment strategies. This review encompasses recently discovered biomarkers of ovarian cancer, the utility of published prognostic biomarkers for EOC (especially biomarkers related to angiogenesis and key signaling pathways), and their integration into clinical practice.

\section{Keywords}

biomarkers; ovarian carcinoma; prognosis

\section{Introduction}

Ovarian cancer remains the most lethal gynecologic cancer due, in part, to the advanced stage at presentation in most patients. ${ }^{1}$ For these patients, surgery followed by chemotherapy remains the standard of care. ${ }^{2}$ Given the diversity in responses, there is a need for highly reliable predictive and prognostic biomarkers. Since the introduction of CA125 as a biomarker for epithelial ovarian cancer (EOC) in 1981, the field of tumor biomarkers has grown substantially. Prognostic markers can help to identify patients at different levels of risk for specific outcomes, facilitate treatment choice, and aid patient counseling. ${ }^{3}$ In oncology, hundreds of prognostic marker studies are published each year. This review provides an overview of current biomarkers in ovarian cancer and their potential utility in clinical practice as prognostic biomarkers (i.e., those that can be used to estimate the chances of disease recurrence) and predictive markers (ie, those associated with response or

\footnotetext{
${ }^{4}$ Correspondence and Reprint Requests: Anil K. Sood, M.D., Professor, Departments of Gynecologic Oncology and Reproductive Medicine, and Cancer Biology, The University of Texas M. D. Anderson Cancer Center, 1155 Herman Pressler Blvd., Unit 1352, Houston, TX 77030, Phone: 713-745-5266, Fax: 713-792-7586, asood@mdanderson.org.
} 
lack of response to a particular therapy). A summary of these biomarkers is provided in Table 1.

\section{Classic Biomarkers of Epithelial Ovarian Cancer}

\subsection{Clinical utility of CA125}

CA125, the first ovarian cancer biomarker ever identified, is a high-molecular-weight glycoprotein recognized by the monoclonal antibody OC125. CA125 is expressed by epithelial ovarian tumors and other tissues of Mullerian origin. Serum CA125 levels are initially elevated in $>80 \%$ of ovarian cancer patients and may be used to reflect the clinical course of disease. ${ }^{4}$ Since Bast and colleagues first produced the OC125 monoclonal antibody in $1981,{ }^{5}$ serum CA125 measurement has been used extensively in clinical practice to screen women at high risk for ovarian cancer, to plan treatment, and to predict clinical course and response to chemotherapy. Despite having limited sensitivity and specificity, serum CA125 estimation is generally agreed to have clinical value during preoperative work-up and during post-treatment monitoring. ${ }^{4,6,7}$ Serum CA125 is also of prognostic significance in predicting patient survival and response to chemotherapy. ${ }^{4-10}$ Therefore, CA125 remains one of the most important prognostic biomarkers for EOC patients in the clinical setting. ${ }^{9-11}$

It is commonly agreed that patients with early-stage EOC are less likely to have an elevated serum CA125 level preoperatively and more likely to have a better prognosis. ${ }^{4,6,7,12}$ One previous study showed a significantly higher survival rate for patients with preoperative serum CA125 $<65 \mathrm{U} / \mathrm{ml}$ than for patients with preoperative serum levels $>65 \mathrm{U} / \mathrm{mL} .{ }^{13}$ Postoperative serum CA125>65 U/mL was also associated with a significantly worse 5 year survival than was postoperative serum CA125 $<65 \mathrm{U} / \mathrm{mL}$ (42\% versus $5 \%$ ). Makar and colleagues found that elevated serum CA125 was an independent prognostic factor for survival, regardless of residual disease status after primary surgery. ${ }^{14}$

2.1.1. CA125 as prognostic factor-In patients without residual disease after primary surgery, significant prognostic factors for survival include histology type, postoperative CA125 level with a cutoff value $35 \mathrm{U} / \mathrm{mL}$, and tumor grade ; for those with residual disease, they are histology type, postoperative CA125 level with cutoff value $65 \mathrm{U} / \mathrm{mL}$, postoperative treatment, and size of residual disease. Dynamic change in serum CA125 level before and after treatment is also an independent prognostic factor for survival. ${ }^{14,15}$ In a $10-$ year European study, Han and collaborators recruited 296 patients who met the criteria of CA125 progression and doubling during surveillance after first-line therapy. During surveillance, the median CA125 doubling time was $40 \mathrm{~d}$; the median survival was shorter for patients whose CA125 doubling time was $\leq 40 \mathrm{~d}$ than for those whose doubling time was > $40 \mathrm{~d}$ (10.6 months versus 22.1 months). On multivariate analysis, short CA125 doubling time ( $\leq 40 \mathrm{~d}$ ) and short time to disease progression (6180 d) remained the only 2 independent adverse prognostic factors. Han et al also confirmed these findings in a set of 28 new patients. Together, their findings suggested that the rate of CA125 increase during surveillance has independent prognostic significance. ${ }^{13}$ Therefore, serum CA125 level should be considered when making therapeutic decisions for EOC patients. 
2.1.2. CA125 as chemoresponsiveness predictor-Dynamic changes in serum CA125 levels can also be used to predict response to first-line and second-line chemotherapy. ${ }^{9}, 16-21$ This enables clinicians to plan primary treatment and to make the most appropriate second-line treatment decisions for patients with EOC. Some investigators have proposed using serum CA125 as a marker in clinical trials of new therapeutic drugs for ovarian cancer, ${ }^{22}$ which is now the case in new EOC drug development. ${ }^{23}$

Karam et al proposed that withholding treatment in the event of isolated rising CA125 levels would not negatively affect these patients' overall survival, ${ }^{24}$ thereby highlighting the need for more efficient clinical use of serum CA125 testing and for new EOC biomarkers. Clinical and basic research aimed at overcoming the drawbacks of CA125 by means of (1) dynamic CA125 monitoring, (2) combination with ultrasonography and other clinical factors such as TNM and stage, and (3) combination with other biomarkers has produced encouraging results. ${ }^{11,15,24-26}$

\section{Novel biomarker development in EOC}

Thanks to the burgeoning development of genomics, proteomics, metabolomics, and other "omics" and an improved understanding of cancer biology over the past 3 decades, hundreds of prognostically valuable EOC biomarkers have been discovered. Some of the most promising of these biomarkers are VEGF, HE4, mesothelin, M-CSF, osteopontin, kallikrein(s), bikunin, EphA2, and soluble EGF receptor, although none surpass CA125. ${ }^{11,25,27-35}$ Those most relevant to the recent clinical focus on targeted and personalized therapy are biomarkers of angiogenesis and related signaling pathways.

\subsection{EOC biomarkers with angiogenic features}

It is well established that angiogenesis (ie, the formation of new blood vessels) is necessary for the growth and metastasis of solid tumors. ${ }^{36}$ Tumor angiogenesis is regulated by a complex, and still not fully understood, interplay between endogenous angiogenic stimulators (such as VEGF and FGF family members) and inhibitors (such as endostatin and thrombospondin-1).$^{37}$ Angiogenic biomarkers have been the subject of recent comprehensive reviews. Alterations in the expression of pro- and anti-angiogenic factors serve not only as markers of solid tumor progression but also as prognostic indicators for EOC. ${ }^{28-33,35,38-40}$

VEGF was the first, and is now the most extensively studied, family of angiogenic factors. VEGF, the most prominent of the angiogenic stimulators, exists in four main forms of 121 , 165, 189 and 206 amino acids in length. Each has a variety of functions, including recruitment and mitogenic stimulation of endothelial cells. ${ }^{41}$ In a study of VEGF expression in tumor specimens from 68 FIGO stage I and II EOC patients, median disease free survival was better in VEGF negative than VEGF positive patients (18 months vs. 120 months), and elevated VEGF expression was associated with poorer survival. ${ }^{29}$ Serum VEGF elevation pretreatment, thought by some to be a good predictor of tumor angiogenesis, correlates significantly with poorer disease-free survival and overall survival. ${ }^{32}$ VEGF-A and other VEGF family members such as VEGF-D are independent prognostic factors in EOC. ${ }^{38}$ Other researchers have reported similar results. ${ }^{28,30,31,33,35,39,42}$ Because VEGF is one of 
the more prominent angiogenic mediators of new tumor vessel growth and also an important endothelial cell survival factor, ${ }^{43}$ it is both a potential biomarker and a potential therapeutic target. Indeed, VEGF targeted therapy has shown clinical promise, ${ }^{44,} 45$ but its therapeutic effect is largely limited to newly forming tumor vessels and is dependent on complicated interactions with other factors such as EGF, PDGF, IL-8, EphA2, and the matrix metalloproteinases. Meanwhile, there is a lack of effective biomarkers for monitoring response to new antivascular agents.

EphA2, a transmembrane receptor tyrosine kinase overexpressed by many human cancers, is another promising angiogenesis-related prognostic biomarker. ${ }^{28,46,47}$ It is often associated with poor prognostic features and tumor angiogenesis. ${ }^{46,}{ }^{47} \mathrm{EphA} 2$ is a member of the largest family of tyrosine kinase receptors The EphA2 family consists of 16 known receptors and 9 known ligands that are categorized into subtypes A and B by the ephrins with which they interact. EphA2 is involved in many processes crucial to malignant progression, such as migration, invasion, metastasis, proliferation, survival, and angiogenesis. It is overexpressed in cancers of the ovary, breast, prostate, lung, colon, esophagus, renal cell, cervix, and melanoma. In many of these malignancies, EphA2 overexpression is associated with poor survival, advanced stage, or increased metastatic potential. In an immunohistochemical study of 94 tissue specimens (EOC and control) by our group, EphA2 overexpression was significantly associated not only with higher tumor grade and advanced stage of disease, but also with significantly shorter survival (median, 3.1 years vs. 12 years for patients with low or absent EphA2 tumor expression), even after multivariate analysis in a Cox proportional hazards model. ${ }^{28}$ Another study in endothelial and ovarian cancer cells revealed a strong association between EphA2 overexpression and the expression of critical tumor angiogenic and invasive factors. ${ }^{47}$

Given the positive association of EphA2 with aggressive clinical and pathological features in human cancers and the cancer-promoting features of EphA2 overexpression, ${ }^{28}$ we have examined the therapeutic potential of downregulating EphA2 expression in preclinical models. We found that silencing EphA2 alone could reduce tumor growth by up to $60 \%$ and, in combination with antibody/paclitaxel therapy, by up to $95 \% .46,48-50$

Our recent study of the enhancer of Zeste homolog 2 (EZH2) showed the functional and biological importance of EZH2 in angiogenesis and tumor growth and the potential value of increased EZH2 expression in either tumor cells or tumor vasculature as a predictor of poor clinical outcome. This suggests the therapeutic potential of targeting EZH2. ${ }^{51}$ Many other angiogenic factors have potential prognostic value in EOC, yet, their prognostic significance has to be confirmed in further studies. These factors include FGF family members, interleukins (especially IL- 6 and IL-8), cell-cell and cell-ECM (extracellular matrix) factors, including several claudin family members (claudin-3, claudin-4, and claudin-7) and matrix metalloproteinases (MMPs) (eg, MMP2 and MMP9), focal adhesion kinase (FAK), and tissue factor (TF), and their alterations in tissue, serum, and other biological fluids including cyst fluid and ascites. ${ }^{51-53}$

Given the role of cytokines in the biology of ovarian cancer cells, the current interest in their diagnostic, monitory, and prognostic uses is not surprising. Interleukins are potent 
endothelial-cell chemo-attractants. Current investigations have focused on IL-6 as a prognostic factor. High IL-6 levels have been associated with unfavorable clinical outcome, ${ }^{54-56}$ though not always consistently. ${ }^{57} \mathrm{IL}-6$ level reflects a large tumor burden, and macrophage activation followed by subsequent release and accumulation of IL-6 in the serum and ascites and the expression of factors that might affect tumor burden and macrophage activation are not easy to control. In one study, IL-6 was no better than traditional markers as a disease biomarker when used alone, but was considered useful when used as part of a panel of cytokines. ${ }^{58}$ Although IL-6-mediated tumor growth and angiogenesis has been demonstrated in ovarian cancer models, ${ }^{59}$ the benefit of IL- 6 as a marker of ovarian tumor angiogenesis remains to be determined. ${ }^{52}$

Interleukin-8, one of the most widely studied cytokines in ovarian cancer, is a potent proangiogenic factor overexpressed in most human cancers, including ovarian carcinoma. ${ }^{60-63}$ Because IL-8 helps mediate tumor angiogenesis, ${ }^{63}$ quantifying circulating IL-8 levels may be a useful biomarker of response. High IL-8 expression has been associated with advanced tumor stage, high tumor grade, and worse survival (median survival for patients with high vs. low IL-8 expression: 1.62 vs. 3.79 years). Increased IL-8 expression has also been associated with poor clinical outcome in human ovarian carcinoma and IL-8 gene silencing with decreased tumor growth via anti-angiogenic mechanisms. ${ }^{64}$

Conversely, others have reported that IL-8 levels increase immediately after the initiation of chemotherapy in ovarian cancer patients, especially in those with residual disease. ${ }^{65}$ This reflects not only the secretion of IL- 8 by multiple sources including monocytes, neutrophils, and mesothelial cells, but also the need for further preclinical investigations of IL-8 as a tumor biomarker. The claudins are integral components of tight junctions (ie, apical cell-cell adhesions that regulate epithelial paracellular permeability and are critical for epithelial cell polarity). In tumor cells, the loss of cell-cell adhesion is central to cellular transformation and metastatic potential. ${ }^{66,67}$ Certain members of the claudin gene family including claudin-3, -4 , and 7 are abnormally regulated in several human cancers including ovarian cancer. ${ }^{68,}{ }^{69}$ Claudin- 3 is overexpressed in $90 \%$ of ovarian tumors, including all 4 major subtypes (serous, mucinous, clear cell, and endometrioid) ${ }^{70}$ and is also associated with shorter survival. ${ }^{71}$ Claudin-3 expression also promotes migration, invasion, and survival of ovarian cancer cells. ${ }^{68,72}$ Conversely, silencing the claudin- 3 gene suppresses ovarian tumor growth and metastasis in mouse tumor models. ${ }^{70}$ Claudin- 4 overexpression in EOC apparently does not correlate with survival or other clinical endpoints. ${ }^{69}$

Tissue MMPs are a large family of zinc- and calcium-dependent proteolytic enzymes that can degrade most components of the extracellular matrix and mediate tumor invasion and metastasis. ${ }^{73}$ The MMPs associated with ovarian carcinomas include MMP-2, MMP-9, and membrane type-1 (MT1)-MMP according to majority of authors. ${ }^{74-78}$ MMP-2, MMP-7, MMP-8, MMP-9, and MT1-MMP have been detected in 54\%, 81\%, 95\%, 97\% and 100\% of EOCs, respectively. ${ }^{78,79}$ Torng et al found stromal MMP-2 expression to be a poor predictor of disease specific survival for patients with endometrioid cancer, but not for those with serous histology. ${ }^{80}$ Davidson et al found MMP-9 mRNA expression in tumor cells to be an independent poor prognostic predictor of survival in patients with EOC. ${ }^{81}$ Others have reported that patients with weak tumor expression of stromal MMP-9 had significantly 
longer survival than did those with moderate or intense expression. ${ }^{82}$ In a study of 90 EOC tissue specimens, Kamet et al reported that high epithelial and stromal expression of MMP-2, MMP-9, and MT1-MMP were each significantly associated with shorter diseasespecific survival on univariate analysis, and that high stromal expression of MMP-9 and MT1-MMP and strong epithelial expression of MT1-MMP were poor independent predictors on multivariate analysis. ${ }^{78}$ In contrast, Westerlund et al reported that, stromal MMP-2 expression correlated with earlier ovarian carcinoma and better prognosis. ${ }^{83}$

Cell migration is an important component of the metastatic process and requires repeated adhesion to and detachment from the extracellular matrix microenvironment. These events are mediated, in large part, by integrins. FAK, an integral component of the integrinsignaling pathway, is a critical mediator of signaling events between cells and their extracellular matrix, thereby facilitating invasion and migration. ${ }^{84} \mathrm{FAK}$ is overexpressed in metastatic human colorectal, breast, thyroid, and prostate cancer cells and ovarian cancer. ${ }^{85-89}$ Its overexpression predicts poor clinical outcome by virtue of its significant association with worse survival (median, 7.6 years versus 2.98 years) ${ }^{90}$ In a series of in vitro and in vivo experiments in which ovarian cancer cells were transfected with the dominant-negative construct FRNK, FAK inhibitor-TAE226, or FAK-siRNA-DOPC separately, the inhibition or silencing of FAK and its phosphorylation significantly reduced tumor burden in multiple tumor models and decreased invasion, migration, and cell spread. ${ }^{40,90,91}$ Further studies are warranted and necessary to translate these experimental findings into clinical practice. Other angiogenic markers, such as tumor cell-lined vasculature, microvessel density (MVD), and stromal compartment, are potentially prognostic and therefore potentially therapeutic in EOC. ${ }^{31,42,47,92,93}$ However, their utility after anti-angiogenic therapy remains to be determined. Consequently, we consider them to be microscopic level markers and outside the scope of this review.

Modern gene array-based profiling approaches have been used to develop EOC angiogenic biomarkers. ${ }^{94,} 95$ Using immunohistochemistry-guided laser-capture microdissection and genome-wide transcriptional profiling techniques, Buckanovich et al identified and validated 12 novel ovarian tumor vascular markers (TVMs) and found that overexpression of any one of three ovarian TVMs by vascular cells was associated with decreased disease-free interval. Using a similar approach, Mendiola et al tested 61 formalin-fixed, paraffin-embedded samples from late stage I EOC patients and generated a 34-gene profile that had independent prognostic value on multivariate analysis. This gene profiling approach will be discussed in more detail later in this review. ${ }^{95}$

Despite the promise of anti-angiogenic therapy for EOC, its potential clinical use remains controversial. ${ }^{27,}$ 96-98 Several of the most promising anti-angiogenic drugs, which target VEGF and VEGF related genes (eg, bevacizumab, sorafenib, sunitinib, and temsirolimus), are already approved by the FDA for use against solid tumors, such as advanced RCC and metastatic colorectal cancer, but their use in EOC remains the focus of preclinical and clinical trials. ${ }^{96}$ Nevertheless, the promising results achieved with angiogenesis-related factors over the last few decades may soon lead to the targeted application of such factors in EOC and their use as biomarkers of clinical course and responsiveness. 


\subsection{Signaling pathway, apoptotic pathway, and genetic/ epigenetic related markers}

Successful biomarker development depends on approaches that originate from the discovery phase and culminate in the clinical validation of an appropriately targeted biomarker. The most frequently reported molecular pathway biomarkers in ovarian cancer are EGF receptor (HER) family members, apoptotic pathway surrogates (such as p53 and cell cycle- related kinases) and DNA repair proteins (such as BRCA1/2 and ERCC1).

3.2.1. EGF receptor (HER) family-The human EGF receptor (HER) family mediates crucial cellular processes, including growth, proliferation, and survival. This receptor family consists of four transmembrane receptors: HER1 (EGFR), HER2, HER3, and HER4. Each receptor has an extracellular binding domain, a transmembrane domain, and an intracellular domain. ${ }^{99,100}$ This receptor is noted for the interdependence and functional complementarity of its members and their tendency to heterodimerize with each other (eg, HER2/HER3, HER2/HER4), traits that have significant implications for the development of targeted therapies. ${ }^{101,102}$ EGFR (HER) - 1,2 and 4 proteins possess tyrosine kinase activities, whereas EGFR(HER)-3 doesn't, but EGFR(HER3)-3 can dimerize with other EGFR(HER) family members and lead to activation of the EGFR(HER) pathways. ${ }^{103}$

EGFR is widely expressed in a variety of human tumors including ovarian, head and neck, breast, and non-small-cell lung (NSCLC) cancers. ${ }^{104}$ Estimates ranging from $60 \%$ to $98 \%$ of all epithelial ovarian cancers express high levels of the EGFR (HER), and extensive studies also revealed that EGFR (HER) had significant implication in tumor growth and progression. ${ }^{103,105-108}$ Two separate groups have shown an inverse correlation between EGFR and survival in ovarian cancer. ${ }^{109,110}$ Others have delineated the key role of EGFR in downstream signaling pathways such as the PI3K (phosphatidylinositol-3 kinase)/Akt and ERK (external signal-regulated kinase) pathways. ${ }^{111}$ Still others have revealed a positive correlation between nuclear EGFR and cyclin D1 and K1-67. ${ }^{112}$

The role of HER2 has been studied in several tumor types, including breast, head and neck, prostate, and ovarian cancer. ${ }^{113}$ In breast cancer, HER2 overexpression varies widely (from $1.8 \%$ to $76 \%) .{ }^{114}$ In a randomized trial, Slamon found HER2 expression in breast and ovarian carcinoma to be indicative of aggressive tumor growth and poor prognosis. ${ }^{115}$ In a Dutch study of 208 patients, mean survival was shorter in patients with HER2-positive tumors than in those with HER-2 negative tumors (17 months vs. 26 months). ${ }^{116}$ Similar findings were made by Tanner et al in a study of 96 women with stage III ovarian cancer (12 months vs 25 months $)^{117}$ and by Felip et al (62 weeks vs. 123 weeks). ${ }^{118}$ Other studies have shown HER2 expression to be an independent prognostic indicator of survival. ${ }^{119,} 120$

In a study of patients with HER2-negative ovarian tumors, Gorden et al found that HER2 was activated in $45 \%$ of the tumors and that HER 2 amplification was not required for any clinical activity associated with pertuzumab. ${ }^{121}$ Others have shown that HER2 may activate key downstream signaling pathways (eg, PI3K-Akt and RAS-Raf-MEK) by dimerizing with other ligand-activated HER receptors, particularly HER3. ${ }^{122-124}$ Indeed, HER2 preferentially binds with HER3, and the resulting HER2/HER3 heterodimer has a strong mitogenic signaling effect. ${ }^{125}$ In a study of 116 consecutive patients with primary EOC, HER3 levels were associated with patient survival on both univariate and multivariate 
analysis. ${ }^{126}$ Moreover, as shown by Kaplan-Meier analysis, patients with low HER3 protein levels $(n=54)$ had a significantly longer median survival time than did patients with high HER3 protein levels $(n=62)$ (3.31 years versus 1.80 years). HER3, lacking of tyrosine kinase activity itself, however, after dimerization with other members of the EGFR family, several signal transduction cascades can be activated, including PI3-K (phosphoinosite 3'kinase)/Akt and extracellular signal-regulated kinase (ERK1/2). In this study, they reported that HER 3 overexpression was observed in $53.4 \%$ of patients. ${ }^{126}$

HER2 and HER3, by themselves, are functionally incomplete receptors and therefore particularly dependent on each other. HER2 has an extracellular domain but no apparent ligand-binding activity, while HER3 has a non-functional kinase domain and no catalytic kinase activity. In contrast, the HER2/HER3 heterodimer is a highly functional signaling unit and is in fact the most active signaling dimer in the HER family. ${ }^{127}$ HER4 mediates antiproliferative effects. However, its overactivity does not appear to play a major role in tumorigenesis. ${ }^{128}$ Moreover, there exists the debate on the prognostic value of EGFR (HER) in EOC. Graeff and colleagues performed a meta-analysis on total 15 EGFR studies, 20 HER-2 /neu studies and 62 p53 studies; they concluded that although p53, EGFR and HER-2/neu status modestly influences survival, these markers are, by themselves, unlikely to be useful as prognostic markers in clinical practice. Thus, further validation based on studies with well-defined, prospective clinical trials and more complete reporting of results are needed. ${ }^{129}$

Biologically targeted antibodies and tyrosine kinase inhibitors directed toward EGFR/ ErbB1/HER1 (eg, cetuximab, erlotinib and gefitinib) and ErbB2/HER2 (eg, trastuzumab), and more recently toward ErbB3/HER3 and ErbB4/HER4, are being investigated as therapies for patients with EGFR/ERBB/HER proto-oncogene-driven malignancies. ${ }^{130}$ Ongoing trials of these agents alone or in combination with traditional chemotherapeutic agents are underway. ${ }^{131}$ Trastuzumab, a monoclonal antibody against HER2, is the standard of care for patients with HER2-positive breast cancer in the metastatic and adjuvant settings and is associated with improved disease-free and overall survival. However, in a phase II trial of single-agent trastuzumab in patients with persistent or recurrent epithelial ovarian or primary peritoneal cancer, no relationship was found between HER 2 expression and clinical response, progression-free survival, or overall survival. ${ }^{132}$ Interestingly, the combination of cytotoxic chemotherapy and EGFR/HER inhibitors seems to provide better clinical response and therefore warrants further evaluation. Inhibition of HER2/HER3 dimerization is a particularly attractive approach to anticancer therapy. ${ }^{124,133}$

\subsubsection{Apoptotic pathway biomarkers}

3.2.2.a. p53: The p53 suppressor gene has come to the forefront of cancer research because it is commonly mutated in human cancer. Thus, detection of p53 abnormalities may have diagnostic, prognostic, and therapeutic implications. p53 is mutated in all major cancers, ${ }^{134}$ and represents the most frequent mutation in ovarian cancer. ${ }^{135} \mathrm{p} 53$ is one of the most important mediators of the intrinsic apoptotic pathway. Upon activation, the p53 protein acts as a tumor suppressor whose genetic effects lead to cell-cycle arrest, apoptosis, senescence, or differentiation. ${ }^{136-138}$ p53 is mutated in $60-80 \%$ of all sporadic EOCs and correlates 
highly with high-grade tumors. ${ }^{139-143}$ Subtype-specific mutations in p53 have been found in almost $60 \%$ of serous tumors but only $16 \%$ of mucinous tumors, ${ }^{144}$ which suggests a prominent role for $\mathrm{p} 53$ mutation in carcinogenesis of serous but not mucinous ovarian tumors. p53 mutation is a late event in ovarian carcinogenesis, and the loss of p53 apparently confers a more aggressive, rapidly growing phenotype. Several studies have examined the prognostic value of p53 antibodies in ovarian cancer. ${ }^{145}$ One study on total 126 patients reported that the plasma $553-\mathrm{Ab}$ positivity was correlated with the highest risk of cancer progression in serous EOC. ${ }^{146}$ In another study of presurgical serum from 104 women with ovarian cancer, p53 antibody was associated with better overall survival. In a meta-analysis, patients with aberrant p53, EGFR, or HER2 tumor status had significantly lower odds of surviving 5 years. Moreover, Goodell and colleagues evaluated the relationship between antibody immunity to the p53 oncogenic protein with EOC outcome, and they demonstrated the presence of $\mathrm{p} 53-\mathrm{Ab}$ was an independent prognostic indicator of overall survival in advanced-stage patients. ${ }^{147}$

Other studies have associated overexpression of mutant p53 with worse survival, FIGO stages, ${ }^{148-151}$ poorer histological grade of differentiation, and high proliferative fraction. Shahin et al observed an association between worse prognosis and p53 mutation status in patients with EOC. Overall, $48.5 \%$ and $57.3 \%$ of tumor samples from those patients showed p53 overexpression and p53 mutation, respectively; and even though neither p53 overexpression nor p53 mutation affected overall survival, the combination did predict worse survival in both univariate and multivariate models. When p53-nonresponsive and p53-null tumors were grouped together as functionally null, the worst prognosis was associated with missense mutations on univariate analysis. Functionally null p53, stage, and optimal cytoreduction were independent prognostic factors on multivariate analysis. More detailed characterization of p53's mutational spectrum and classification of mutations according to their effect on p53 functionality have led some groups to hypothesize that distinct types of mutations can shorten survival. ${ }^{152,153}$ However, there is no consensus to date, and regardless of tumor stage, the effect of p53 mutation status on overall survival remains questionable. Some studies have found no association between any p53 alteration and prognosis. ${ }^{154-156}$

3.2.2.b. Cell cycle-related kinases: Cell cycle deregulation is a hallmark of carcinoma. ${ }^{37}$ CCRK (cycle-related kinase) is frequently overexpressed in brain, renal cell, and ovarian cancers and is expressed either weakly or not at all in normal ovarian epithelial tissue. ${ }^{157,} 158$ In a study by Wu et al, overexpression of CCRK in ovarian carcinomas correlated strongly with ascending histopathological grade, poor differentiation, and/or advanced clinical stage and thus served as an independent predictor of shorter overall survival. Upregulated expression of CCRK in ovarian carcinomas might involve the cyclin D1-associated pathway. Cyclin D1 is essential for G1 phase progression and is a candidate proto-oncogene. ${ }^{159}$ Cyclin D1 overexpression is associated with tumor characteristics and clinical outcome in many cancers including ovarian cancer. ${ }^{160-166}$ In a study of 134 patients with serous EOC, ${ }^{167}$ cyclin D1 overexpression (>10\% versus $\leq 10 \%$ ) was an independent predictor of poor survival. Such findings, however, are not fully consistent with those by other groups. ${ }^{168,169}$ In a Cox regression analysis, Barbieri et al found that women with 
cyclin D1-overexpressing ovarian adenocarcinomas and residual disease $>2 \mathrm{~cm}$ after surgery had significantly shorter survival than those who did not (relative risk(RR) of death: 2.48 and 3.7, respectively). These investigators did not, however, note any significant difference in cyclin D1 overexpression between histologic subtypes. ${ }^{168}$ On the other hand, Masciullo et al ${ }^{165}$ found that overexpression of cyclin D1 mRNA in EOC was significantly associated with well-differentiated and moderately well-differentiated tumor grade (grade 12) but not with clinical outcome and other parameters. Moreover, no association has been found between the presence of cyclin D1 expression and clinical outcome. ${ }^{161,164,} 168$ These contrasting results are likely due to differences in analytical techniques and scoring systems used in those studies. ${ }^{170}$

The role of cyclin $\mathrm{E}$ in oncogenesis and its function as a clinical prognostic indicator in cancer patients have been the focus of many reports in recent years. Cyclin E has been consistently associated with disease progression in various malignancies and with poor prognosis in patients with breast, bladder, colorectal, and ovarian carcinoma. ${ }^{171-178}$ Cyclin E gene amplification has been detected in $12 \%$ to $21 \%$ of ovarian tumors, ${ }^{177-179}$ RNA overexpression in up to $30 \%$ cases, ${ }^{177-179}$ and protein overexpression in up to $70 \% .{ }^{180-182}$ Together, these findings suggest that cyclin $\mathrm{E}$ is an important mediator of survival and its expression an independent predictor of poor prognosis in patients with ovarian carcinoma. Overexpression of the cyclin E protein has been linked to shortening of the G1 phase of the cell cycle, decreased requirement for growth factors, enhanced cell proliferation, induction of chromosomal instability, and polyploidy. ${ }^{172,183-186}$ These processes contribute to the oncogenic potential of cyclin E. Cyclin E's prognostic value is debatable. Rosen et al demonstrated that a high level of cyclin $\mathrm{E}$ is an independent predictor of poor prognosis. ${ }^{187}$ Sui et al correlated increased cyclin E expression with tumor progression and poor prognosis in EOC patients. ${ }^{180}$ In contrast, others have found no correlation between cyclin E expression and survival in patients with ovarian carcinoma 167,188 or only a trend toward an association with a poor prognosis. ${ }^{189}$

3.2.3. BRCA1 and BRCA2-The BRCA1 and BRCA2 tumor suppressor genes help regulate cellular proliferation, chromosomal stability, and DNA repair via homologous recombination. They help maintain genomic stability by recognizing and mediating repair of DNA damage, regulating transcription, and controlling cell cycle checkpoints through p53dependent and independent mechanisms. ${ }^{190-192}$ Approximately $10 \%$ of breast and ovarian carcinomas are due to a genetic predisposition (mainly germline mutations in the BRCA1 and BRCA2 genes). ${ }^{190}$ Females carrying BRCA1 or BRCA2 mutations have a $16 \%-60 \%$ and a 16\%-27\% lifetime risk, respectively, of developing EOC. ${ }^{190,193}$ Studies in high-risk families indicate that mutations in BRCA1 or BRCA2 genes confer as much as an $87 \%$ risk of breast cancer and $44 \%$ risk of ovarian cancer by the age of 70 (with mean age of onset 510 years earlier than in non-carriers) and that the vast majority of these patients will have serous adenocarcinomas. ${ }^{194-196}$ Interestingly, however, most studies indicate that women with a BRCA1 or 2-related ovarian cancer have better survival than non-carriers, 197-204 particularly if they receive platinum-based therapy. ${ }^{201-204}$ In vitro studies have shown that some BRCA1 mutated ovarian cell lines have increased sensitivity to various chemotherapeutic agents. ${ }^{171}$ These findings are supported by an unbiased historical cohort 
study of Ashkenazi Jews in which ovarian cancer outcomes were better for BRCA1 or 2 mutation carriers than for non-carriers ${ }^{199}$ and by studies showing a more favorable response to chemotherapy among patients with hereditary ovarian cancer. ${ }^{199,200,205,206}$

3.2.4. ERCC-ERCC1 (excision repair cross-complementation group 1) is a major mediator of nucleotide excision repair (NER), a process that can correct most bulky lesions in DNA. ${ }^{207}$ ERCC1 overexpression is a potential marker of prognosis and of tumor resistance to platinum-based chemotherapy regimens in many cancers, including EOC. ${ }^{207-214}$ In patients with advanced EOC, higher levels of serum ERCC1 protein are often associated with widespread metastasis, enhanced DNA damage repair, and tumor aggressiveness. On the contrary, lower levels of ERCC1 (and resulting lower rates of DNA repair and increased early senescence and apoptosis of tumor cells) are often associated with slower metastasis and fewer lesions, which might render such tumors more amenable to optimal debulking surgery. ${ }^{211}$ Studies in EOC patients support this view. ERCC1 was shown to be an independent prognostic marker of debulking outcome, and ERCC protein expression was associated with survival or response to platinum compounds (but not always with debulking outcome). ${ }^{215,216}$

\subsection{Epithelial ovarian cancer biomarkers with immune signatures}

Given the well-established importance of the immune system in tumor development, ${ }^{217}, 218$ researchers are striving to find novel immune-related prognostic biomarkers. Zhang and colleagues reported that the presence of intratumoral $\mathrm{T}$ cells correlated with improved clinical outcome in advanced ovarian carcinoma from a study on 186 ovarian cancer specimens. They found that the five-year overall survival rate was $38 \%$ in patients with positive intratumoral $\mathrm{T}$ cells, compared with $4.5 \%$ in patients without $\mathrm{T}$ cells in tumor islets. They also found significant differences in progression-free survival and overall survival according to the presence or absence of intratumoral $\mathrm{T}$ cells in 74 patients with a complete clinical response after debulking and platinum-based chemotherapy (the five-year overall survival rate: $73.9 \%$ vs. $11.9 \%$ ). The presence of intratumoral T cells independently correlated with delayed recurrence or delayed death on multivariate analysis and was associated with increased intratumoral expression of interferon, interleukin-2, and lymphocyte-attracting chemokines. The absence of intratumoral $\mathrm{T}$ cells was associated with increased levels of vascular endothelial growth factor. ${ }^{219}$

Several novel immune-related biomarkers of EOC have independent prognostic value. One of these is the antigen processing machinery (APM) components. Han and colleagues were the first to report that APM downregulation and lack of intratumoral T-cell infiltrates are independent prognostic markers for death from ovarian carcinoma. In their study of 150 tumor samples from patients with invasive EOC, they found that most tumors expressed TAP1, TAP2, HLA-HC, and $\beta_{2}$ microglobulin either heterogeneously or positively; $67 \%$ possessed intratumoral $\mathrm{CD}^{+}$or $\mathrm{CD}^{+}$cells; and $88 \%$ possessed peritumoral $\mathrm{CD}^{+}{ }^{+}$or $\mathrm{CD}^{+}$ cells. ${ }^{220}$ Another prognostically valuable immune-related biomarker is B7-H3. Recently, Zang et al reported that B7-H3 (one of the B7 family members of immunoregulatory ligands), positive tumor vasculature was associated with significantly shorter survival time 
and a higher incidence of recurrence. ${ }^{221}$ Together, these findings imply the critical role of immune surveillance and immune escape in the clinical course of EOC.

\subsection{MicroRNA, Dicer, and Drosha --- EOC biomarkers on the frontier of discovery}

Recently, a new epigenetic regulatory program was identified with the discovery of small non-coding microRNAs (miRNAs) in Caenorhabditis elegans. ${ }^{222}$ MiRNAs are endogenous, small non-coding RNAs (approximately 22 nucleotides) that negatively regulate gene expression at the posttranscriptional level in a sequence-specific manner. ${ }^{223-226}$ miRNAs may play a role in cancer development and progression. For instance, loss of miRNAmediated gene regulation may be a tumorigenic mechanism, ${ }^{223}$ impaired miRNA processing may enhance cellular transformation and tumourigenesis, ${ }^{227}$ and miRNAs may act as oncogenes or tumor suppressor genes. ${ }^{228,} 229$ These insights have stimulated investigations into miRNA's role in ovarian cancer. An early study showed that approximately $40 \%$ of miRNA genes exhibit altered DNA copy numbers. ${ }^{230}$ More recent studies have shown that deregulation of miRNAs affects survival and drug resistance. ${ }^{226,231,232}$ In a study by Nam et al, higher expression of miR-200, miR-141, miR-18a, miR-93, and miR-429, and lower expression of let-7b, and miR-199a correlated significantly with poor prognosis. ${ }^{246}$ In a study by Yang et al, miR-214, miR-199*, and miR-200a were associated with high-grade and late-stage ovarian tumors. ${ }^{63}$ Other studies have shown that miRNAs may be useful in predicting ovarian carcinoma outcome. ${ }^{233}$ For example, many members of the let-7 protein family act as tumor suppressors, and patients with low let-7a-3 methylation levels have worse overall survival than those with high methylation levels. ${ }^{233}$ In addition, even though most miRNAs are downregulated in cancer tissues, some are upregulated in recurrent as opposed to primary tumors.

Increased knowledge of the RNA-interference machinery and its 2 main components- the miRNAs Dicer and Drosha—has led to investigations of their use as diagnostic, prognostic, and therapeutic biomarkers in cancer. ${ }^{234-238}$ In mammalian miRNA biogenesis, the primary transcripts of miRNA genes (pri-miRNAs) are cleaved into hairpin intermediates (premiRNAs) by Drosha (nuclear RNase III) and further processed into mature miRNAs by cytosolic Dicer (another RNase III-related enzyme). ${ }^{233}$ Dysregulation of miRNA secondary to the defects in RNA silencing machinery has been observed in several types of tumors including ovarian cancers. ${ }^{238,239}$ We were the first to report that low Dicer expression independently predicted poor outcomes in ovarian cancer patients. ${ }^{238}$ In line with our results, Faggad et al provided evidence that the decreased expression of Dicer has functional consequences for miRNA expression and leads to a global downregulation of miRNA expression and significant changes in gene expression. ${ }^{240}$ When we extended our analysis to other tumor types using mRNA expression profiling data, we confirmed a similar relationship between Dicer expression and outcomes in lung, breast, and other cancers 239,241 Dicer expression appears to be upregulated in non-invasive precursors of invasive lung adenocarcinoma. ${ }^{239}$ Contrary findings in other tumor types have been reported (ie, correlation of high Dicer and Drosha expression with poor prognosis in prostate cancer $^{239}$ and no correlation of Dicer expression with outcome in acute myeloid leukemia), ${ }^{242}$ although these discrepancies might be explained by tissue specificity. 
Suzuki et al have forged a link between the tumor suppressor p53 and posttranscriptional maturation of miRNAs by demonstrating that p53 interacts with the Drosha microprocessor complex through DEAD-box RNA helicase p68 (DDX5) to facilitate the processing of primiRNAs into pre-miRNAs. ${ }^{243}$ Recently, Wu et al reported that TAp63, a p53 family member, suppresses tumorigenesis and metastasis through the coordinate regulation of Dicer and miR-130b by directly binding and trans-activating the Dicer promoter, thereby demonstrating direct transcriptional regulation of Dicer by TAp63. ${ }^{241}$

\subsection{Plasma cell free DNA}

Circulating plasma cell free nucleic acids, now known to be mainly tumor derived, ${ }^{244,} 245$ were discovered by Mandel in 1948. ${ }^{246}$ They are detected in the blood of both healthy and sick individuals, and their concentration is generally related to tumor load and disease extent. Patients suffering from malignant diseases like EOC usually have increased amounts of circulating cell free nucleic acids. Tumors release genomic DNA into the systemic circulation, probably through cellular necrosis and apoptosis. ${ }^{247,} 248$ Such tumor-specific cell free DNA may be detected in the plasma by the presence of genetic and epigenetic alterations specific to the primary tumor. ${ }^{249-251}$ This makes tumor-specific cell free DNA potential tumor biomarkers and therapeutic targets.

Fiegl and colleagues have found that persistence of RASSFIA DNA methylation of cell free DNA 1 year after primary surgery and adjuvant tamoxifen therapy is an independent predictor of poor outcome in breast cancer. ${ }^{252}$ In an orthotopic EOC mouse model, we have shown that cell free DNA levels correlate closely with tumor load and that those levels decline appreciably with chemotherapy. ${ }^{253}$ Consequently, cell-free DNA is a potential prognostic marker in several solid tumors, including ovarian cancer. ${ }^{254-256}$ We have reported that cell-free DNA at concentrations $>22,000 \mathrm{GE} / \mathrm{mL}$ is significantly associated with decreased patient survival. After adjusting for other clinical variables, preoperative cell-free DNA >22,000 GE/mL was an independent predictor for disease-specific survival. This suggests that serial monitoring of plasma nucleic acids may be useful for monitoring disease status and predict outcome. Zachariah and colleagues found higher levels of cell-free nuclear and mitochondrial DNA in ovarian cancer patients than in healthy controls but no correlation between cell-free DNA and prognosis. ${ }^{257}$ Further prospective studies on larger numbers of patients are needed to validate the prognostic value of cell-free DNA.

\section{Combination of EOC prognostic biomarkers}

The continuing discovery of new biomarkers of EOC raises the question of how to use them effectively. As already stated above, CA125 has often been combined with other biomarkers. ${ }^{26,258-260}$ Jacob et al have included it in their Risk of Malignancy Index (RMI), which combines serum CA125 level, ultrasound results, and menopausal status to help identify and triage high risk patients by estimating background cancer risk. They found that patients with RMI scores $>200$ had 42 times the background risk and that patients with lower scores had 0.15 times the risk. ${ }^{261}$

The development of effective biomarker combinations will ultimately rely on the proper design and appropriate use of systemic models and analyses. ${ }^{262,263}$ One clinical trial in 
200,000 women in the United Kingdom is now utilizing an algorithm to evaluate the ability of a 2-stage screening strategy to improve survival in ovarian cancer. More than 30 serum markers besides CA125 will be required to detect all patients in an initial phase of screening and will then need to be evaluated alone and in combination with CA125 by different investigators. ${ }^{25}$

\section{Challenges and future directions}

Despite years of research and mushrooming reports of new tumor biomarkers, the number of clinically useful markers is pitifully small. ${ }^{264}$ This is partly due to the complex nature of the tumor biomarkers themselves-especially those at the DNA, RNA, and protein levels-and partly due to the lack of acceptable standards for effectively evaluating and incorporating these newer biomarkers in the clinic. Thus, further validation and effective translation are needed. In addition, most prognostic studies in cancer are not protocol driven or prospective but retrospective. ${ }^{265}$ Retrospective studies offer the distinct advantage of large cohorts whose follow-up periods are long enough to allow assessment of a substantial number of outcomes of interest. Conversely, their disadvantages include unclear inclusion criteria, cohort completeness and follow-up; incomplete baseline data; lack of standardization of diagnostic and therapeutic procedures; and statistical analytical issues. ${ }^{3}$ Thus, validation and randomized clinical trials are needed to determine the true value of the new biomarkers for early diagnosis and improved survival and quality of life.

The first challenge is to establish acceptable criteria for evaluating new biomarkers and for standardizing the information that is gained in an integrated and clinically useful setting. ${ }^{266}$ In 2005, REMARK proposed guidelines meant to encourage more clarity and comprehensiveness in biomarker studies. ${ }^{267}$ It is imperative to establish integrated, clinically feasible criteria for tumor biomarker studies and to design and conduct prospective studies that use a reliable model, and enroll sufficient numbers of patients, and are properly and comprehensively analyzed statistically. ${ }^{268}$ Although it is important to seek a convergence of findings across multiple, independent data sets, it is only through the accumulation of evidence that tumor biomarkers in EOC can begin to be validated clinically. ${ }^{258,259,} 269$

An important obstacle to the development of clinically useful tumor biomarkers is the availability of techniques for detecting them. Cancer-associated biomarkers in blood exist at low concentrations within complex mixtures of very abundant proteins, such as albumin and immunoglobulins, and there can be serious physiologic challenges to separating them out.

Advances in nanotechnology are providing a completely new approach to this problem. For example, Liotta created a nanoparticle for biomarker "harvesting" that rapidly concentrates and amplifies scarce proteins for mass spectrometry analysis, multiple reaction monitoring, or immunoassay-based analysis. ${ }^{270}$

During the past decade, a growing knowledge of tumor biomarkers has been translated into targeted and personalized clinical therapies. One successful example is anti-angiogenesis therapy based on the developing knowledge of angiogenic biomarkers. ${ }^{28,} 46,48,49,50,96$ Another is the use of targeted drugs such as trastuzumab to target the HER2 proto-oncogene and EGFR inhibitors to block the EGFR signaling pathway. ${ }^{262,} 263$ In 2007, in an attempt to 
speed up the drug development process, improve safety and efficacy, and increase the cost efficiency of using tumor biomarkers to identify potentially useful new cancer drugs, the AACR-FDA-NCI Cancer Biomarkers Collaborative launched a national effort to clearly delineate the barriers to such research, develop recommendations for integrating biomarkers into the cancer drug development enterprise, and set in motion the necessary action plans and collaborations. ${ }^{271}$ Further efforts are needed to advance the use of biomarkers in cancer drug development and in the improvement of patient survival and quality of life.

In the near future, continued collaboration between clinicians, statisticians, and others should lead to establishment of clinically feasible criteria for biomarker studies, integration of reliable and statistically robust biomarker information into clinical treatment planning guidelines, and the development of more effective targeted strategies based on the knowledge gained from tumor biomarkers.

\section{Acknowledgments}

Portions of this work were supported by National Institutes of Health (CA 110793, 109298, P50 CA083639, P50 CA098258, CA128797, RC2GM092599, U54 CA151668), the Ovarian Cancer Research Fund, Inc. (Program Project Development Grant), the Department of Defense (OC073399, OC093146, BC085265), the Marcus Foundation, and the Betty Anne Asche Murray Distinguished Professorship, and NCI institutional Core Grant CA16672.

\section{References}

1. Jemal A, Siegel R, Xu J, Ward E. Cancer statistics, 2010. CA Cancer J Clin. 60:277-300. [PubMed: 20610543]

2. Ferte C, Andre F, Soria JC. Molecular circuits of solid tumors: prognostic and predictive tools for bedside use. Nat Rev Clin Oncol. 7:367-380. [PubMed: 20551944]

3. Altman DG, Riley RD. Primer: an evidence-based approach to prognostic markers. Nat Clin Pract Oncol. 2005; 2:466-472. [PubMed: 16265015]

4. Jacobs I, Bast RC Jr. The CA 125 tumour-associated antigen: a review of the literature. Hum Reprod. 1989; 4:1-12. [PubMed: 2651469]

5. Bast RC Jr, Feeney M, Lazarus H, Nadler LM, Colvin RB, Knapp RC. Reactivity of a monoclonal antibody with human ovarian carcinoma. J Clin Invest. 1981; 68:1331-1337. [PubMed: 7028788]

6. Einhorn N, Bast RC Jr, Knapp RC, Tjernberg B, Zurawski VR Jr. Preoperative evaluation of serum CA 125 levels in patients with primary epithelial ovarian cancer. Obstet Gynecol. 1986; 67:414416. [PubMed: 2418395]

7. Vasilev SA, Schlaerth JB, Campeau J, Morrow CP. Serum CA 125 levels in preoperative evaluation of pelvic masses. Obstet Gynecol. 1988; 71:751-756. [PubMed: 3162763]

8. Yarbro JW, Page DL, Fielding LP, Partridge EE, Murphy GP. American Joint Committee on Cancer prognostic factors consensus conference. Cancer. 1999; 86:2436-2446. [PubMed: 10590388]

9. Fayers PM, Rustin G, Wood R, et al. The prognostic value of serum CA 125 in patients with advanced ovarian carcinoma: an analysis of 573 patients by the Medical Research Council Working Party on Gynaecological Cancer. Int J Gynecol Cancer. 1993; 3:285-292. [PubMed: 11578359]

10. Rustin GJ, Bast RC Jr, Kelloff GJ, et al. Use of CA-125 in clinical trial evaluation of new therapeutic drugs for ovarian cancer. Clin Cancer Res. 2004; 10:3919-3926. [PubMed: 15173101]

11. Anderson GL. Ovarian cancer biomarker screening: still too early to tell. Womens Health (Lond Engl). 6:487-490. [PubMed: 20597610]

12. Seidman JD, Yemelyanova AV, Khedmati F, et al. Prognostic factors for stage I ovarian carcinoma. Int J Gynecol Pathol. 29:1-7. [PubMed: 19952945] 
13. Kaesemann H, Caffier H, Hoffmann FJ, et al. [Monoclonal antibodies in the diagnosis and followup of ovarian cancer. CA 125 as a tumor marker. A cooperative study of the Gynecologic Tumor Marker Group (GTMG)]. Klin Wochenschr. 1986; 64:781-785. [PubMed: 3463828]

14. Makar AP, Kristensen GB, Kaern J, Bormer OP, Abeler VM, Trope CG. Prognostic value of preand postoperative serum CA 125 levels in ovarian cancer: new aspects and multivariate analysis. Obstet Gynecol. 1992; 79:1002-1010. [PubMed: 1579296]

15. Han LY, Karavasilis V, Hagen T, et al. Doubling time of serum CA125 is an independent prognostic factor for survival in patients with ovarian cancer relapsing after first-line chemotherapy. Eur J Cancer. 46:1359-1364. [PubMed: 20303743]

16. Gronlund B, Hogdall C, Hilden J, Engelholm SA, Hogdall EV, Hansen HH. Should CA-125 response criteria be preferred to response evaluation criteria in solid tumors (RECIST) for prognostication during second-line chemotherapy of ovarian carcinoma? J Clin Oncol. 2004; 22:4051-4058. [PubMed: 15364966]

17. Gadducci A, Cosio S, Tana R, Genazzani AR. Serum and tissue biomarkers as predictive and prognostic variables in epithelial ovarian cancer. Crit Rev Oncol Hematol. 2009; 69:12-27. [PubMed: 18595727]

18. Crawford SM, Peace J. Does the nadir CA125 concentration predict a long-term outcome after chemotherapy for carcinoma of the ovary? Ann Oncol. 2005; 16:47-50. [PubMed: 15598937]

19. Gadducci A, Cosio S, Fanucchi A, Negri S, Cristofani R, Genazzani AR. The predictive and prognostic value of serum CA 125 half-life during paclitaxel/platinum-based chemotherapy in patients with advanced ovarian carcinoma. Gynecol Oncol. 2004; 93:131-136. [PubMed: 15047226]

20. Meyer T, Rustin GJ. Role of tumour markers in monitoring epithelial ovarian cancer. Br J Cancer. 2000; 82:1535-1538. [PubMed: 10789720]

21. Rocconi RP, Matthews KS, Kemper MK, Hoskins KE, Huh WK, Straughn JM Jr. The timing of normalization of CA-125 levels during primary chemotherapy is predictive of survival in patients with epithelial ovarian cancer. Gynecol Oncol. 2009; 114:242-245. [PubMed: 19447480]

22. Rustin GJ, Nelstrop AE, Bentzen SM, Bond SJ, McClean P. Selection of active drugs for ovarian cancer based on CA-125 and standard response rates in phase II trials. J Clin Oncol. 2000; 18:1733-1739. [PubMed: 10764434]

23. Piccart MJ, Gore M, Ten Bokkel Huinink W, et al. Docetaxel: an active new drug for treatment of advanced epithelial ovarian cancer. J Natl Cancer Inst. 1995; 87:676-681. [PubMed: 7752272]

24. Karam AK, Karlan BY. Ovarian cancer: the duplicity of CA125 measurement. Nat Rev Clin Oncol. 7:335-339. [PubMed: 20368726]

25. Bast RC Jr, Badgwell D, Lu Z, et al. New tumor markers: CA125 and beyond. Int J Gynecol Cancer. 2005; 15(Suppl 3):274-281. [PubMed: 16343244]

26. Menon U, Gentry-Maharaj A, Hallett R, et al. Sensitivity and specificity of multimodal and ultrasound screening for ovarian cancer, and stage distribution of detected cancers: results of the prevalence screen of the UK Collaborative Trial of Ovarian Cancer Screening (UKCTOCS). Lancet Oncol. 2009; 10:327-340. [PubMed: 19282241]

27. Coticchia CM, Yang J, Moses MA. Ovarian cancer biomarkers: current options and future promise. J Natl Compr Canc Netw. 2008; 6:795-802. [PubMed: 18926090]

28. Thaker PH, Deavers M, Celestino J, et al. EphA2 expression is associated with aggressive features in ovarian carcinoma. Clin Cancer Res. 2004; 10:5145-5150. [PubMed: 15297418]

29. Paley PJ, Staskus KA, Gebhard K, et al. Vascular endothelial growth factor expression in early stage ovarian carcinoma. Cancer. 1997; 80:98-106. [PubMed: 9210714]

30. Siddiqui GK, Elmasry K, Wong Te Fong AC, et al. Prognostic significance of intratumoral vascular endothelial growth factor as a marker of tumour angiogenesis in epithelial ovarian cancer. Eur J Gynaecol Oncol. 31:156-159. [PubMed: 20527230]

31. Sonmezer M, Gungor M, Ensari A, Ortac F. Prognostic significance of tumor angiogenesis in epithelial ovarian cancer: in association with transforming growth factor beta and vascular endothelial growth factor. Int J Gynecol Cancer. 2004; 14:82-88. [PubMed: 14764033] 
32. Chen CA, Cheng WF, Lee CN, et al. Serum vascular endothelial growth factor in epithelial ovarian neoplasms: correlation with patient survival. Gynecol Oncol. 1999; 74:235-240. [PubMed: 10419737]

33. Spannuth WA, Nick AM, Jennings NB, et al. Functional significance of VEGFR-2 on ovarian cancer cells. Int J Cancer. 2009; 124:1045-1053. [PubMed: 19058181]

34. Bamberger ES, Perrett CW. Angiogenesis in epithelian ovarian cancer. Mol Pathol. 2002; 55:348359. [PubMed: 12456770]

35. Tempfer C, Obermair A, Hefler L, Haeusler G, Gitsch G, Kainz C. Vascular endothelial growth factor serum concentrations in ovarian cancer. Obstet Gynecol. 1998; 92:360-363. [PubMed: 9721770]

36. Folkman J. Endothelial cells and angiogenic growth factors in cancer growth and metastasis. Introduction. Cancer Metastasis Rev. 1990; 9:171-174. [PubMed: 1705485]

37. Hanahan D, Weinberg RA. The hallmarks of cancer. Cell. 2000; 100:57-70. [PubMed: 10647931]

38. Yokoyama Y, Charnock-Jones DS, Licence D, et al. Vascular endothelial growth factor-D is an independent prognostic factor in epithelial ovarian carcinoma. Br J Cancer. 2003; 88:237-244. [PubMed: 12610509]

39. Engels K, du Bois A, Harter P, et al. VEGF-A and i-NOS expression are prognostic factors in serous epithelial ovarian carcinomas after complete surgical resection. J Clin Pathol. 2009; 62:448-454. [PubMed: 19126566]

40. Halder J, Lin YG, Merritt WM, et al. Therapeutic efficacy of a novel focal adhesion kinase inhibitor TAE226 in ovarian carcinoma. Cancer Res. 2007; 67:10976-10983. [PubMed: 18006843]

41. Charlesworth PJ, Harris AL. Mechanisms of disease: angiogenesis in urologic malignancies. Nat Clin Pract Urol. 2006; 3:157-169. [PubMed: 16528288]

42. Sood AK, Fletcher MS, Zahn CM, et al. The clinical significance of tumor cell-lined vasculature in ovarian carcinoma: implications for anti-vasculogenic therapy. Cancer Biol Ther. 2002; 1:661664. [PubMed: 12642690]

43. Gerber HP, McMurtrey A, Kowalski J, et al. Vascular endothelial growth factor regulates endothelial cell survival through the phosphatidylinositol 3'-kinase/Akt signal transduction pathway. Requirement for Flk-1/KDR activation. J Biol Chem. 1998; 273:30336-30343. [PubMed: 9804796]

44. Hurwitz H, Fehrenbacher L, Novotny W, et al. Bevacizumab plus irinotecan, fluorouracil, and leucovorin for metastatic colorectal cancer. N Engl J Med. 2004; 350:2335-2342. [PubMed: 15175435]

45. Jain RK, Duda DG, Clark JW, Loeffler JS. Lessons from phase III clinical trials on anti-VEGF therapy for cancer. Nat Clin Pract Oncol. 2006; 3:24-40. [PubMed: 16407877]

46. Landen CN, Kinch MS, Sood AK. EphA2 as a target for ovarian cancer therapy. Expert Opin Ther Targets. 2005; 9:1179-1187. [PubMed: 16300469]

47. Lin YG, Han LY, Kamat AA, et al. EphA2 overexpression is associated with angiogenesis in ovarian cancer. Cancer. 2007; 109:332-340. [PubMed: 17154180]

48. Chon HS, Hu W, Kavanagh JJ. Targeted therapies in gynecologic cancers. Curr Cancer Drug Targets. 2006; 6:333-363. [PubMed: 16848724]

49. Landen CN Jr, Lu C, Han LY, et al. Efficacy and antivascular effects of EphA2 reduction with an agonistic antibody in ovarian cancer. J Natl Cancer Inst. 2006; 98:1558-1570. [PubMed: 17077358]

50. Yang N, Kaur S, Volinia S, et al. MicroRNA microarray identifies Let-7i as a novel biomarker and therapeutic target in human epithelial ovarian cancer. Cancer Res. 2008; 68:10307-10314. [PubMed: 19074899]

51. Lu C, Han HD, Mangala LS, et al. Regulation of tumor angiogenesis by EZH2. Cancer Cell. 18:185-197. [PubMed: 20708159]

52. Merritt WM, Sood AK. Markers of angiogenesis in ovarian cancer. Dis Markers. 2007; 23:419431. [PubMed: 18057525] 
53. Landen CN Jr, Chavez-Reyes A, Bucana C, et al. Therapeutic EphA2 gene targeting in vivo using neutral liposomal small interfering RNA delivery. Cancer Res. 2005; 65:6910-6918. [PubMed: 16061675]

54. Berek JS, Chung C, Kaldi K, Watson JM, Knox RM, Martinez-Maza O. Serum interleukin-6 levels correlate with disease status in patients with epithelial ovarian cancer. Am J Obstet Gynecol. 1991; 164:1038-1042. discussion 1042-1033. [PubMed: 2014824]

55. Scambia G, Testa U, Benedetti Panici P, et al. Prognostic significance of interleukin 6 serum levels in patients with ovarian cancer. Br J Cancer. 1995; 71:354-356. [PubMed: 7841052]

56. Tempfer C, Zeisler H, Sliutz G, Haeusler G, Hanzal E, Kainz C. Serum evaluation of interleukin 6 in ovarian cancer patients. Gynecol Oncol. 1997; 66:27-30. [PubMed: 9234916]

57. Plante M, Rubin SC, Wong GY, Federici MG, Finstad CL, Gastl GA. Interleukin-6 level in serum and ascites as a prognostic factor in patients with epithelial ovarian cancer. Cancer. 1994; 73:1882-1888. [PubMed: 8137215]

58. Gorelik E, Landsittel DP, Marrangoni AM, et al. Multiplexed immunobead-based cytokine profiling for early detection of ovarian cancer. Cancer Epidemiol Biomarkers Prev. 2005; 14:981987. [PubMed: 15824174]

59. Nilsson MB, Langley RR, Fidler IJ. Interleukin-6, secreted by human ovarian carcinoma cells, is a potent proangiogenic cytokine. Cancer Res. 2005; 65:10794-10800. [PubMed: 16322225]

60. Lokshin AE, Winans M, Landsittel D, et al. Circulating IL-8 and anti-IL-8 autoantibody in patients with ovarian cancer. Gynecol Oncol. 2006; 102:244-251. [PubMed: 16434085]

61. Xie K. Interleukin-8 and human cancer biology. Cytokine Growth Factor Rev. 2001; 12:375-391. [PubMed: 11544106]

62. Kassim SK, El-Salahy EM, Fayed ST, et al. Vascular endothelial growth factor and interleukin-8 are associated with poor prognosis in epithelial ovarian cancer patients. Clin Biochem. 2004; 37:363-369. [PubMed: 15087251]

63. Koch AE, Polverini PJ, Kunkel SL, et al. Interleukin-8 as a macrophage-derived mediator of angiogenesis. Science. 1992; 258:1798-1801. [PubMed: 1281554]

64. Merritt WM, Lin YG, Spannuth WA, et al. Effect of interleukin-8 gene silencing with liposomeencapsulated small interfering RNA on ovarian cancer cell growth. J Natl Cancer Inst. 2008; 100:359-372. [PubMed: 18314475]

65. Uslu R, Sanli UA, Dikmen Y, et al. Predictive value of serum interleukin-8 levels in ovarian cancer patients treated with paclitaxel-containing regimens. Int J Gynecol Cancer. 2005; 15:240-245. [PubMed: 15823106]

66. Balch CM, Gershenwald JE, Soong SJ, et al. Final version of 2009 AJCC melanoma staging and classification. J Clin Oncol. 2009; 27:6199-6206. [PubMed: 19917835]

67. Miyoshi J, Takai Y. Molecular perspective on tight-junction assembly and epithelial polarity. Adv Drug Deliv Rev. 2005; 57:815-855. [PubMed: 15820555]

68. Morin PJ. Claudin proteins in human cancer: promising new targets for diagnosis and therapy. Cancer Res. 2005; 65:9603-9606. [PubMed: 16266975]

69. Tassi RA, Bignotti E, Falchetti M, et al. Claudin-7 expression in human epithelial ovarian cancer. Int J Gynecol Cancer. 2008; 18:1262-1271. [PubMed: 18298564]

70. Huang YH, Bao Y, Peng W, et al. Claudin-3 gene silencing with siRNA suppresses ovarian tumor growth and metastasis. Proc Natl Acad Sci U S A. 2009; 106:3426-3430. [PubMed: 19208807]

71. Choi YL, Kim J, Kwon MJ, et al. Expression profile of tight junction protein claudin 3 and claudin 4 in ovarian serous adenocarcinoma with prognostic correlation. Histol Histopathol. 2007; 22:1185-1195. [PubMed: 17647191]

72. Agarwal R, D'Souza T, Morin PJ. Claudin-3 and claudin-4 expression in ovarian epithelial cells enhances invasion and is associated with increased matrix metalloproteinase- 2 activity. Cancer Res. 2005; 65:7378-7385. [PubMed: 16103090]

73. Yurchenco PD, Schittny JC. Molecular architecture of basement membranes. FASEB J. 1990; 4:1577-1590. [PubMed: 2180767]

74. Ellerbroek SM, Fishman DA, Kearns AS, Bafetti LM, Stack MS. Ovarian carcinoma regulation of matrix metalloproteinase-2 and membrane type 1 matrix metalloproteinase through beta1 integrin. Cancer Res. 1999; 59:1635-1641. [PubMed: 10197640] 
75. Fishman DA, Bafetti LM, Stack MS. Membrane-type matrix metalloproteinase expression and matrix metalloproteinase-2 activation in primary human ovarian epithelial carcinoma cells. Invasion Metastasis. 1996; 16:150-159. [PubMed: 9186550]

76. Davidson B, Goldberg I, Gotlieb WH, et al. High levels of MMP-2, MMP-9, MT1-MMP and TIMP-2 mRNA correlate with poor survival in ovarian carcinoma. Clin Exp Metastasis. 1999; 17:799-808. [PubMed: 11089877]

77. Stack MS, Ellerbroek SM, Fishman DA. The role of proteolytic enzymes in the pathology of epithelial ovarian carcinoma. Int J Oncol. 1998; 12:569-576. [PubMed: 9472094]

78. Kamat AA, Fletcher M, Gruman LM, et al. The clinical relevance of stromal matrix metalloproteinase expression in ovarian cancer. Clin Cancer Res. 2006; 12:1707-1714. [PubMed: 16551853]

79. Stadlmann S, Pollheimer J, Moser PL, et al. Cytokine-regulated expression of collagenase-2 (MMP-8) is involved in the progression of ovarian cancer. Eur J Cancer. 2003; 39:2499-2505. [PubMed: 14602136]

80. Torng PL, Mao TL, Chan WY, Huang SC, Lin CT. Prognostic significance of stromal metalloproteinase-2 in ovarian adenocarcinoma and its relation to carcinoma progression. Gynecol Oncol. 2004; 92:559-567. [PubMed: 14766248]

81. Davidson B, Goldberg I, Gotlieb WH, et al. The prognostic value of metalloproteinases and angiogenic factors in ovarian carcinoma. Mol Cell Endocrinol. 2002; 187:39-45. [PubMed: 11988310]

82. Ozalp S, Tanir HM, Yalcin OT, Kabukcuoglu S, Oner U, Uray M. Prognostic value of matrix metalloproteinase-9 (gelatinase-B) expression in epithelial ovarian tumors. Eur J Gynaecol Oncol. 2003; 24:417-420. [PubMed: 14584660]

83. Westerlund A, Apaja-Sarkkinen M, Hoyhtya M, Puistola U, Turpeenniemi-Hujanen T. Gelatinase A-immunoreactive protein in ovarian lesions- prognostic value in epithelial ovarian cancer. Gynecol Oncol. 1999; 75:91-98. [PubMed: 10502432]

84. Schaller MD, Parsons JT. Focal adhesion kinase: an integrin-linked protein tyrosine kinase. Trends Cell Biol. 1993; 3:258-262. [PubMed: 14731743]

85. Owens LV, Xu L, Craven RJ, et al. Overexpression of the focal adhesion kinase (p125FAK) in invasive human tumors. Cancer Res. 1995; 55:2752-2755. [PubMed: 7796399]

86. Cance WG, Harris JE, Iacocca MV, et al. Immunohistochemical analyses of focal adhesion kinase expression in benign and malignant human breast and colon tissues: correlation with preinvasive and invasive phenotypes. Clin Cancer Res. 2000; 6:2417-2423. [PubMed: 10873094]

87. Owens LV, Xu L, Dent GA, et al. Focal adhesion kinase as a marker of invasive potential in differentiated human thyroid cancer. Ann Surg Oncol. 1996; 3:100-105. [PubMed: 8770310]

88. Ayaki M, Komatsu K, Mukai M, et al. Reduced expression of focal adhesion kinase in liver metastases compared with matched primary human colorectal adenocarcinomas. Clin Cancer Res. 2001; 7:3106-3112. [PubMed: 11595702]

89. Judson PL, He X, Cance WG, Van Le L. Overexpression of focal adhesion kinase, a protein tyrosine kinase, in ovarian carcinoma. Cancer. 1999; 86:1551-1556. [PubMed: 10526262]

90. Sood AK, Coffin JE, Schneider GB, et al. Biological significance of focal adhesion kinase in ovarian cancer: role in migration and invasion. Am J Pathol. 2004; 165:1087-1095. [PubMed: 15466376]

91. Shahzad MM, Lu C, Lee JW, et al. Dual targeting of EphA2 and FAK in ovarian carcinoma. Cancer Biol Ther. 2009; 8:1027-1034. [PubMed: 19395869]

92. Labiche A, Heutte N, Herlin P, Chasle J, Gauduchon P, Elie N. Stromal compartment as a survival prognostic factor in advanced ovarian carcinoma. Int J Gynecol Cancer. 20:28-33. [PubMed: 20130500]

93. Weidner N. Tumor angiogenesis: review of current applications in tumor prognostication. Semin Diagn Pathol. 1993; 10:302-313. [PubMed: 7511250]

94. Thijssen VL, Brandwijk RJ, Dings RP, Griffioen AW. Angiogenesis gene expression profiling in xenograft models to study cellular interactions. Exp Cell Res. 2004; 299:286-293. [PubMed: 15350528] 
95. Mendiola M, Barriuso J, Redondo A, et al. Angiogenesis-related gene expression profile with independent prognostic value in advanced ovarian carcinoma. PLoS One. 2008; 3:e4051. [PubMed: 19112514]

96. Sessa C, Guibal A, Del Conte G, Ruegg C. Biomarkers of angiogenesis for the development of antiangiogenic therapies in oncology: tools or decorations? Nat Clin Pract Oncol. 2008; 5:378391. [PubMed: 18560389]

97. Gadducci A, Viacava P, Cosio S, et al. Vascular endothelial growth factor (VEGF) expression in primary tumors and peritoneal metastases from patients with advanced ovarian carcinoma. Anticancer Res. 2003; 23:3001-3008. [PubMed: 12926153]

98. Yamamoto S, Konishi I, Mandai M, et al. Expression of vascular endothelial growth factor (VEGF) in epithelial ovarian neoplasms: correlation with clinicopathology and patient survival, and analysis of serum VEGF levels. Br J Cancer. 1997; 76:1221-1227. [PubMed: 9365173]

99. Grunwald V, Hidalgo M. The epidermal growth factor receptor: a new target for anticancer therapy. Curr Probl Cancer. 2002; 26:109-164. [PubMed: 12085086]

100. See HT, Kavanagh JJ, Hu W, Bast RC. Targeted therapy for epithelial ovarian cancer: current status and future prospects. Int J Gynecol Cancer. 2003; 13:701-734. [PubMed: 14675307]

101. Mass RD. The HER receptor family: a rich target for therapeutic development. Int J Radiat Oncol Biol Phys. 2004; 58:932-940. [PubMed: 14967453]

102. Hsieh AC, Moasser MM. Targeting HER proteins in cancer therapy and the role of the non-target HER3. Br J Cancer. 2007; 97:453-457. [PubMed: 17667926]

103. Vaidya AP, Parnes AD, Seiden MV. Rationale and clinical experience with epidermal growth factor receptor inhibitors in gynecologic malignancies. Curr Treat Options Oncol. 2005; 6:103114. [PubMed: 15717992]

104. Salomon DS, Brandt R, Ciardiello F, Normanno N. Epidermal growth factor-related peptides and their receptors in human malignancies. Crit Rev Oncol Hematol. 1995; 19:183-232. [PubMed: 7612182]

105. Maurizi M, Almadori G, Ferrandina G, et al. Prognostic significance of epidermal growth factor receptor in laryngeal squamous cell carcinoma. Br J Cancer. 1996; 74:1253-1257. [PubMed: 8883413]

106. Fischer-Colbrie J, Witt A, Heinzl H, et al. EGFR and steroid receptors in ovarian carcinoma: comparison with prognostic parameters and outcome of patients. Anticancer Res. 1997; 17:613619. [PubMed: 9066588]

107. Kersemaekers AM, Fleuren GJ, Kenter GG, et al. Oncogene alterations in carcinomas of the uterine cervix: overexpression of the epidermal growth factor receptor is associated with poor prognosis. Clin Cancer Res. 1999; 5:577-586. [PubMed: 10100709]

108. Mellon K, Wright C, Kelly P, Horne CH, Neal DE. Long-term outcome related to epidermal growth factor receptor status in bladder cancer. J Urol. 1995; 153:919-925. [PubMed: 7853575]

109. Nicholson RI, Gee JM, Harper ME. EGFR and cancer prognosis. Eur J Cancer. 2001; 37(Suppl 4):S9-S15. [PubMed: 11597399]

110. Maihle NJ, Baron AT, Barrette BA, et al. EGF/ErbB receptor family in ovarian cancer. Cancer Treat Res. 2002; 107:247-258. [PubMed: 11775453]

111. Tanaka Y, Terai Y, Tanabe A, et al. Prognostic effect of epidermal growth factor receptor gene mutations and the aberrant phosphorylation of Akt and ERK in ovarian cancer. Cancer Biol Ther. 11

112. Xia W, Wei Y, Du Y, et al. Nuclear expression of epidermal growth factor receptor is a novel prognostic value in patients with ovarian cancer. Mol Carcinog. 2009; 48:610-617. [PubMed: 19058255]

113. Hynes NE. Amplification and overexpression of the erbB-2 gene in human tumors: its involvement in tumor development, significance as a prognostic factor, and potential as a target for cancer therapy. Semin Cancer Biol. 1993; 4:19-26. [PubMed: 8095411]

114. Serrano-Olvera A, Duenas-Gonzalez A, Gallardo-Rincon D, Candelaria M, De la Garza-Salazar J. Prognostic, predictive and therapeutic implications of HER2 in invasive epithelial ovarian cancer. Cancer Treat Rev. 2006; 32:180-190. [PubMed: 16483720] 
115. Slamon DJ, Godolphin W, Jones LA, et al. Studies of the HER-2/neu proto-oncogene in human breast and ovarian cancer. Science. 1989; 244:707-712. [PubMed: 2470152]

116. Meden H, Marx D, Roegglen T, Schauer A, Kuhn W. Overexpression of the oncogene c-erbB-2 (HER2/neu) and response to chemotherapy in patients with ovarian cancer. Int J Gynecol Pathol. 1998; 17:61-65. [PubMed: 9475194]

117. Tanner B, Kreutz E, Weikel W, et al. Prognostic significance of c-erB-2 mRNA in ovarian carcinoma. Gynecol Oncol. 1996; 62:268-277. [PubMed: 8751560]

118. Felip E, Del Campo JM, Rubio D, Vidal MT, Colomer R, Bermejo B. Overexpression of cerbB-2 in epithelial ovarian cancer. Prognostic value and relationship with response to chemotherapy. Cancer. 1995; 75:2147-2152. [PubMed: 7697606]

119. Hogdall EV, Christensen L, Kjaer SK, et al. Distribution of HER-2 overexpression in ovarian carcinoma tissue and its prognostic value in patients with ovarian carcinoma: from the Danish MALOVA Ovarian Cancer Study. Cancer. 2003; 98:66-73. [PubMed: 12833457]

120. Camilleri-Broet S, Hardy-Bessard AC, Le Tourneau A, et al. HER-2 overexpression is an independent marker of poor prognosis of advanced primary ovarian carcinoma: a multicenter study of the GINECO group. Ann Oncol. 2004; 15:104-112. [PubMed: 14679128]

121. Gordon MS, Matei D, Aghajanian C, et al. Clinical activity of pertuzumab (rhuMAb 2C4), a HER dimerization inhibitor, in advanced ovarian cancer: potential predictive relationship with tumor HER2 activation status. J Clin Oncol. 2006; 24:4324-4332. [PubMed: 16896006]

122. Yarden Y, Sliwkowski MX. Untangling the ErbB signalling network. Nat Rev Mol Cell Biol. 2001; 2:127-137. [PubMed: 11252954]

123. Rowinsky EK. The erbB family: targets for therapeutic development against cancer and therapeutic strategies using monoclonal antibodies and tyrosine kinase inhibitors. Annu Rev Med. 2004; 55:433-457. [PubMed: 14746530]

124. Amler LC. HER3 mRNA as a predictive biomarker in anticancer therapy. Expert Opin Biol Ther. 10:1343-1355. [PubMed: 20695834]

125. Junttila TT, Akita RW, Parsons K, et al. Ligand-independent HER2/HER3/PI3K complex is disrupted by trastuzumab and is effectively inhibited by the PI3K inhibitor GDC-0941. Cancer Cell. 2009; 15:429-440. [PubMed: 19411071]

126. Tanner B, Hasenclever D, Stern K, et al. ErbB-3 predicts survival in ovarian cancer. J Clin Oncol. 2006; 24:4317-4323. [PubMed: 16896008]

127. Tzahar E, Waterman H, Chen X, et al. A hierarchical network of interreceptor interactions determines signal transduction by Neu differentiation factor/neuregulin and epidermal growth factor. Mol Cell Biol. 1996; 16:5276-5287. [PubMed: 8816440]

128. Naresh A, Long W, Vidal GA, et al. The ERBB4/HER4 intracellular domain 4ICD is a BH3-only protein promoting apoptosis of breast cancer cells. Cancer Res. 2006; 66:6412-6420. [PubMed: 16778220]

129. de Graeff P, Crijns AP, de Jong S, et al. Modest effect of p53, EGFR and HER-2/neu on prognosis in epithelial ovarian cancer: a meta-analysis. Br J Cancer. 2009; 101:149-159. [PubMed: 19513073]

130. Baron AT, Wilken JA, Haggstrom DE, Goodrich ST, Maihle NJ. Clinical implementation of soluble EGFR (sEGFR) as a theragnostic serum biomarker of breastm lung and ovarian cancer. IDrugs. 2009; 12:302-308. [PubMed: 19431095]

131. Palayekar MJ, Herzog TJ. The emerging role of epidermal growth factor receptor inhibitors in ovarian cancer. Int J Gynecol Cancer. 2008; 18:879-890. [PubMed: 18053062]

132. Bookman MA, Darcy KM, Clarke-Pearson D, Boothby RA, Horowitz IR. Evaluation of monoclonal humanized anti-HER2 antibody, trastuzumab, in patients with recurrent or refractory ovarian or primary peritoneal carcinoma with overexpression of HER2: a phase II trial of the Gynecologic Oncology Group. J Clin Oncol. 2003; 21:283-290. [PubMed: 12525520]

133. Frederick PJ, Straughn JM Jr, Alvarez RD, Buchsbaum DJ. Preclinical studies and clinical utilization of monoclonal antibodies in epithelial ovarian cancer. Gynecol Oncol. 2009; 113:384390. [PubMed: 19232697] 
134. Greenblatt MS, Bennett WP, Hollstein M, Harris CC. Mutations in the p53 tumor suppressor gene: clues to cancer etiology and molecular pathogenesis. Cancer Res. 1994; 54:4855-4878. [PubMed: 8069852]

135. Berchuck A, Kohler MF, Marks JR, Wiseman R, Boyd J, Bast RC Jr. The p53 tumor suppressor gene frequently is altered in gynecologic cancers. Am J Obstet Gynecol. 1994; 170:246-252. [PubMed: 8296829]

136. Kastan MB, Onyekwere O, Sidransky D, Vogelstein B, Craig RW. Participation of p53 protein in the cellular response to DNA damage. Cancer Res. 1991; 51:6304-6311. [PubMed: 1933891]

137. Fritsche M, Haessler C, Brandner G. Induction of nuclear accumulation of the tumor-suppressor protein p53 by DNA-damaging agents. Oncogene. 1993; 8:307-318. [PubMed: 8426740]

138. Diller L, Kassel J, Nelson CE, et al. p53 functions as a cell cycle control protein in osteosarcomas. Mol Cell Biol. 1990; 10:5772-5781. [PubMed: 2233717]

139. Henriksen R, Strang P, Wilander E, Backstrom T, Tribukait B, Oberg K. p53 expression in epithelial ovarian neoplasms: relationship to clinical and pathological parameters, Ki-67 expression and flow cytometry. Gynecol Oncol. 1994; 53:301-306. [PubMed: 8206402]

140. Hartmann LC, Podratz KC, Keeney GL, et al. Prognostic significance of p53 immunostaining in epithelial ovarian cancer. J Clin Oncol. 1994; 12:64-69. [PubMed: 8270986]

141. Levesque MA, Katsaros D, Yu H, et al. Mutant p53 protein overexpression is associated with poor outcome in patients with well or moderately differentiated ovarian carcinoma. Cancer. 1995; 75:1327-1338. [PubMed: 7882283]

142. Milner BJ, Allan LA, Eccles DM, et al. p53 mutation is a common genetic event in ovarian carcinoma. Cancer Res. 1993; 53:2128-2132. [PubMed: 8481915]

143. Anttila MA, Ji H, Juhola MT, Saarikoski SV, Syrjanen KJ. The prognostic significance of p53 expression quantitated by computerized image analysis in epithelial ovarian cancer. Int J Gynecol Pathol. 1999; 18:42-51. [PubMed: 9891240]

144. Tammela J, Odunsi K. Gene expression and prognostic significance in ovarian cancer. Minerva Ginecol. 2004; 56:495-502. [PubMed: 15729202]

145. Tomsova M, Melichar B. Contribution of immunohistochemistry in prognostic assessment of epithelial ovarian carcinoma --review of the literature I. Acta Medica (Hradec Kralove). 2006; 49:161-165. [PubMed: 17117604]

146. Dobrzycka B, Terlikowski SJ, Kinalski M, Kowalczuk O, Niklinska W, Chyczewski L. Circulating free DNA and p53 antibodies in plasma of patients with ovarian epithelial cancers. Ann Oncol.

147. Goodell V, Salazar LG, Urban N, et al. Antibody immunity to the p53 oncogenic protein is a prognostic indicator in ovarian cancer. J Clin Oncol. 2006; 24:762-768. [PubMed: 16391298]

148. Kihana T, Tsuda H, Teshima S, Okada S, Matsuura S, Hirohashi S. High incidence of p53 gene mutation in human ovarian cancer and its association with nuclear accumulation of p53 protein and tumor DNA aneuploidy. Jpn J Cancer Res. 1992; 83:978-984. [PubMed: 1429209]

149. Zheng J, Benedict WF, Xu HJ, et al. Genetic disparity between morphologically benign cysts contiguous to ovarian carcinomas and solitary cystadenomas. J Natl Cancer Inst. 1995; 87:11461153. [PubMed: 7674319]

150. Kappes S, Milde-Langosch K, Kressin P, et al. p53 mutations in ovarian tumors, detected by temperature-gradient gel electrophoresis, direct sequencing and immunohistochemistry. Int $\mathrm{J}$ Cancer. 1995; 64:52-59. [PubMed: 7665249]

151. Laframboise S, Chapman W, McLaughlin J, Andrulis IL. p53 mutations in epithelial ovarian cancers: possible role in predicting chemoresistance. Cancer J. 2000; 6:302-308. [PubMed: 11079169]

152. Rose SL, Robertson AD, Goodheart MJ, Smith BJ, DeYoung BR, Buller RE. The impact of p53 protein core domain structural alteration on ovarian cancer survival. Clin Cancer Res. 2003; 9:4139-4144. [PubMed: 14519637]

153. Fallows S, Price J, Atkinson RJ, Johnston PG, Hickey I, Russell SE. P53 mutation does not affect prognosis in ovarian epithelial malignancies. J Pathol. 2001; 194:68-75. [PubMed: 11329143] 
154. Smith-Sorensen B, Kaern J, Holm R, Dorum A, Trope C, Borresen-Dale AL. Therapy effect of either paclitaxel or cyclophosphamide combination treatment in patients with epithelial ovarian cancer and relation to TP53 gene status. Br J Cancer. 1998; 78:375-381. [PubMed: 9703286]

155. Niwa K, Itoh M, Murase T, et al. Alteration of p53 gene in ovarian carcinoma: clinicopathological correlation and prognostic significance. Br J Cancer. 1994; 70:1191-1197. [PubMed: 7981076]

156. Wang Y, Kringen P, Kristensen GB, et al. Effect of the codon 72 polymorphism (c.215G>C, p.Arg72Pro) in combination with somatic sequence variants in the TP53 gene on survival in patients with advanced ovarian carcinoma. Hum Mutat. 2004; 24:21-34. [PubMed: 15221786]

157. Ng SS, Cheung YT, An XM, et al. Cell cycle-related kinase: a novel candidate oncogene in human glioblastoma. J Natl Cancer Inst. 2007; 99:936-948. [PubMed: 17565152]

158. Boer JM, Huber WK, Sultmann H, et al. Identification and classification of differentially expressed genes in renal cell carcinoma by expression profiling on a global human 31,500element cDNA array. Genome Res. 2001; 11:1861-1870. [PubMed: 11691851]

159. Sherr CJ. Mammalian G1 cyclins. Cell. 1993; 73:1059-1065. [PubMed: 8513492]

160. Gillett C, Fantl V, Smith R, et al. Amplification and overexpression of cyclin D1 in breast cancer detected by immunohistochemical staining. Cancer Res. 1994; 54:1812-1817. [PubMed: 8137296]

161. Callender T, el-Naggar AK, Lee MS, Frankenthaler R, Luna MA, Batsakis JG. PRAD-1 (CCND1)/cyclin D1 oncogene amplification in primary head and neck squamous cell carcinoma. Cancer. 1994; 74:152-158. [PubMed: 8004570]

162. Nishida N, Fukuda Y, Komeda T, et al. Amplification and overexpression of the cyclin D1 gene in aggressive human hepatocellular carcinoma. Cancer Res. 1994; 54:3107-3110. [PubMed: 8205525]

163. Hall M, Peters G. Genetic alterations of cyclins, cyclin-dependent kinases, and Cdk inhibitors in human cancer. Adv Cancer Res. 1996; 68:67-108. [PubMed: 8712071]

164. Worsley SD, Ponder BA, Davies BR. Overexpression of cyclin D1 in epithelial ovarian cancers. Gynecol Oncol. 1997; 64:189-195. [PubMed: 9038263]

165. Masciullo V, Scambia G, Marone M, et al. Altered expression of cyclin D1 and CDK4 genes in ovarian carcinomas. Int J Cancer. 1997; 74:390-395. [PubMed: 9291427]

166. Barbieri F, Cagnoli M, Ragni N, Pedulla F, Foglia G, Alama A. Expression of cyclin D1 correlates with malignancy in human ovarian tumours. Br J Cancer. 1997; 75:1263-1268. [PubMed: 9155044]

167. Bali A, O'Brien PM, Edwards LS, Sutherland RL, Hacker NF, Henshall SM. Cyclin D1, p53, and p21Waf1/Cip1 expression is predictive of poor clinical outcome in serous epithelial ovarian cancer. Clin Cancer Res. 2004; 10:5168-5177. [PubMed: 15297421]

168. Barbieri F, Cagnoli M, Ragni N, et al. Increased cyclin D1 expression is associated with features of malignancy and disease recurrence in ovarian tumors. Clin Cancer Res. 1999; 5:1837-1842. [PubMed: 10430089]

169. Sui L, Tokuda M, Ohno M, Hatase O, Hando T. The concurrent expression of p27(kip1) and cyclin D1 in epithelial ovarian tumors. Gynecol Oncol. 1999; 73:202-209. [PubMed: 10329035]

170. Chen CH, Shen J, Lee WJ, Chow SN. Overexpression of cyclin D1 and c-Myc gene products in human primary epithelial ovarian cancer. Int J Gynecol Cancer. 2005; 15:878-883. [PubMed: 16174239]

171. Thangaraju M, Kaufmann SH, Couch FJ. BRCA1 facilitates stress-induced apoptosis in breast and ovarian cancer cell lines. J Biol Chem. 2000; 275:33487-33496. [PubMed: 10938285]

172. Lengauer C, Kinzler KW, Vogelstein B. Genetic instability in colorectal cancers. Nature. 1997; 386:623-627. [PubMed: 9121588]

173. Bani-Hani KE, Almasri NM, Khader YS, Sheyab FM, Karam HN. Combined evaluation of expressions of cyclin $\mathrm{E}$ and $\mathrm{p} 53$ proteins as prognostic factors for patients with gastric cancer. Clin Cancer Res. 2005; 11:1447-1453. [PubMed: 15746045]

174. Fukuse T, Hirata T, Naiki H, Hitomi S, Wada H. Prognostic significance of cyclin E overexpression in resected non-small cell lung cancer. Cancer Res. 2000; 60:242-244. [PubMed: 10667567] 
175. Ferreri AJ, Ponzoni M, Pruneri G, et al. Immunoreactivity for p27(KIP1) and cyclin E is an independent predictor of survival in primary gastric non-Hodgkin's lymphoma. Int J Cancer. 2001; 94:599-604. [PubMed: 11745451]

176. Courjal F, Louason G, Speiser P, Katsaros D, Zeillinger R, Theillet C. Cyclin gene amplification and overexpression in breast and ovarian cancers: evidence for the selection of cyclin D1 in breast and cyclin E in ovarian tumors. Int J Cancer. 1996; 69:247-253. [PubMed: 8797862]

177. Farley J, Smith LM, Darcy KM, et al. Cyclin E expression is a significant predictor of survival in advanced, suboptimally debulked ovarian epithelial cancers: a Gynecologic Oncology Group study. Cancer Res. 2003; 63:1235-1241. [PubMed: 12649182]

178. Yamamoto S, Tsuda H, Miyai K, Takano M, Tamai S, Matsubara O. Cumulative alterations of p27-related cell-cycle regulators in the development of endometriosis-associated ovarian clear cell adenocarcinoma. Histopathology. 56:740-749. [PubMed: 20546339]

179. Marone M, Scambia G, Giannitelli C, et al. Analysis of cyclin E and CDK2 in ovarian cancer: gene amplification and RNA overexpression. Int J Cancer. 1998; 75:34-39. [PubMed: 9426687]

180. Sui L, Dong Y, Ohno M, et al. Implication of malignancy and prognosis of p27(kip1), Cyclin E, and Cdk2 expression in epithelial ovarian tumors. Gynecol Oncol. 2001; 83:56-63. [PubMed: 11585414]

181. Todd MC, Spruill SC, Meerbrey KL. Small interference RNA-mediated suppression of overexpressed cyclin E protein restores G1/S regulation in NIH-OVCAR-3 ovarian cancer cells. Int J Oncol. 2009; 35:375-380. [PubMed: 19578752]

182. Shimizu M, Nikaido T, Toki T, Shiozawa T, Fujii S. Clear cell carcinoma has an expression pattern of cell cycle regulatory molecules that is unique among ovarian adenocarcinomas. Cancer. 1999; 85:669-677. [PubMed: 10091740]

183. Ohtsubo M, Roberts JM. Cyclin-dependent regulation of G1 in mammalian fibroblasts. Science. 1993; 259:1908-1912. [PubMed: 8384376]

184. Bedrosian I, Lu KH, Verschraegen C, Keyomarsi K. Cyclin E deregulation alters the biologic properties of ovarian cancer cells. Oncogene. 2004; 23:2648-2657. [PubMed: 15007381]

185. Akli S, Zheng PJ, Multani AS, et al. Tumor-specific low molecular weight forms of cyclin E induce genomic instability and resistance to p21, p27, and antiestrogens in breast cancer. Cancer Res. 2004; 64:3198-3208. [PubMed: 15126360]

186. Spruck CH, Won KA, Reed SI. Deregulated cyclin E induces chromosome instability. Nature. 1999; 401:297-300. [PubMed: 10499591]

187. Rosen DG, Yang G, Deavers MT, et al. Cyclin E expression is correlated with tumor progression and predicts a poor prognosis in patients with ovarian carcinoma. Cancer. 2006; 106:1925-1932. [PubMed: 16568440]

188. Blegen H, Einhorn N, Sjovall K, et al. Prognostic significance of cell cycle proteins and genomic instability in borderline, early and advanced stage ovarian carcinomas. Int J Gynecol Cancer. 2000; 10:477-487. [PubMed: 11240718]

189. Milde-Langosch K, Hagen M, Bamberger AM, Loning T. Expression and prognostic value of the cell-cycle regulatory proteins, Rb, p16MTS1, p21WAF1, p27KIP1, cyclin E, and cyclin D2, in ovarian cancer. Int J Gynecol Pathol. 2003; 22:168-174. [PubMed: 12649672]

190. Scully R, Livingston DM. In search of the tumour-suppressor functions of BRCA1 and BRCA2. Nature. 2000; 408:429-432. [PubMed: 11100717]

191. Leegte B, van der Hout AH, Deffenbaugh AM, et al. Phenotypic expression of double heterozygosity for BRCA1 and BRCA2 germline mutations. J Med Genet. 2005; 42:e20. [PubMed: 15744030]

192. Warner E, Foulkes W, Goodwin P, et al. Prevalence and penetrance of BRCA1 and BRCA2 gene mutations in unselected Ashkenazi Jewish women with breast cancer. J Natl Cancer Inst. 1999; 91:1241-1247. [PubMed: 10413426]

193. Piura B, Rabinovich A, Yanai-Inbar I. Three primary malignancies related to BRCA mutation successively occurring in a BRCA1 185delAG mutation carrier. Eur J Obstet Gynecol Reprod Biol. 2001; 97:241-244. [PubMed: 11451557]

194. Ford D, Easton DF, Bishop DT, Narod SA, Goldgar DE. Risks of cancer in BRCA1-mutation carriers. Breast Cancer Linkage Consortium. Lancet. 1994; 343:692-695. [PubMed: 7907678] 
195. Ford D, Easton DF, Stratton M, et al. Genetic heterogeneity and penetrance analysis of the BRCA1 and BRCA2 genes in breast cancer families. The Breast Cancer Linkage Consortium. Am J Hum Genet. 1998; 62:676-689. [PubMed: 9497246]

196. Matzuk MM. Gynecologic diseases get their genes. Nat Med. 2005; 11:24-26. [PubMed: 15635441]

197. Rubin SC, Benjamin I, Behbakht K, et al. Clinical and pathological features of ovarian cancer in women with germ-line mutations of BRCA1. N Engl J Med. 1996; 335:1413-1416. [PubMed: 8875917]

198. Aida H, Takakuwa K, Nagata H, et al. Clinical features of ovarian cancer in Japanese women with germ-line mutations of BRCA1. Clin Cancer Res. 1998; 4:235-240. [PubMed: 9516977]

199. Boyd J, Sonoda Y, Federici MG, et al. Clinicopathologic features of BRCA-linked and sporadic ovarian cancer. JAMA. 2000; 283:2260-2265. [PubMed: 10807385]

200. Ben David Y, Chetrit A, Hirsh-Yechezkel G, et al. Effect of BRCA mutations on the length of survival in epithelial ovarian tumors. J Clin Oncol. 2002; 20:463-466. [PubMed: 11786575]

201. Majdak EJ, Debniak J, Milczek T, et al. Prognostic impact of BRCA1 pathogenic and BRCA1/ BRCA2 unclassified variant mutations in patients with ovarian carcinoma. Cancer. 2005; 104:1004-1012. [PubMed: 16047333]

202. Chetrit A, Hirsh-Yechezkel G, Ben-David Y, Lubin F, Friedman E, Sadetzki S. Effect of BRCA1/2 mutations on long-term survival of patients with invasive ovarian cancer: the national Israeli study of ovarian cancer. J Clin Oncol. 2008; 26:20-25. [PubMed: 18165636]

203. Tan DS, Rothermundt C, Thomas K, et al. "BRCAness" syndrome in ovarian cancer: a casecontrol study describing the clinical features and outcome of patients with epithelial ovarian cancer associated with BRCA1 and BRCA2 mutations. J Clin Oncol. 2008; 26:5530-5536. [PubMed: 18955455]

204. Frumovitz M, Schmeler KM, Malpica A, Sood AK, Gershenson DM. Unmasking the complexities of mucinous ovarian carcinoma. Gynecol Oncol. 117:491-496. [PubMed: 20332054]

205. Ramus SJ, Fishman A, Pharoah PD, Yarkoni S, Altaras M, Ponder BA. Ovarian cancer survival in Ashkenazi Jewish patients with BRCA1 and BRCA2 mutations. Eur J Surg Oncol. 2001; 27:278-281. [PubMed: 11373105]

206. Cass I, Baldwin RL, Varkey T, Moslehi R, Narod SA, Karlan BY. Improved survival in women with BRCA-associated ovarian carcinoma. Cancer. 2003; 97:2187-2195. [PubMed: 12712470]

207. Dabholkar M, Vionnet J, Bostick-Bruton F, Yu JJ, Reed E. Messenger RNA levels of XPAC and ERCC1 in ovarian cancer tissue correlate with response to platinum-based chemotherapy. J Clin Invest. 1994; 94:703-708. [PubMed: 8040325]

208. Walsh CS, Ogawa S, Karahashi H, et al. ERCC5 is a novel biomarker of ovarian cancer prognosis. J Clin Oncol. 2008; 26:2952-2958. [PubMed: 18565881]

209. Ceppi P, Volante M, Novello S, et al. ERCC1 and RRM1 gene expressions but not EGFR are predictive of shorter survival in advanced non-small-cell lung cancer treated with cisplatin and gemcitabine. Ann Oncol. 2006; 17:1818-1825. [PubMed: 16980606]

210. Reed E, Yu JJ, Davies A, Gannon J, Armentrout SL. Clear cell tumors have higher mRNA levels of ERCC1 and XPB than other histological types of epithelial ovarian cancer. Clin Cancer Res. 2003; 9:5299-5305. [PubMed: 14614013]

211. Selvakumaran M, Pisarcik DA, Bao R, Yeung AT, Hamilton TC. Enhanced cisplatin cytotoxicity by disturbing the nucleotide excision repair pathway in ovarian cancer cell lines. Cancer Res. 2003; 63:1311-1316. [PubMed: 12649192]

212. Weberpals J, Garbuio K, O'Brien A, et al. The DNA repair proteins BRCA1 and ERCC1 as predictive markers in sporadic ovarian cancer. Int J Cancer. 2009; 124:806-815. [PubMed: 19035454]

213. Lin K, Ye D, Xie X. Protein expression levels of excision repair cross-complementation group 1 and xeroderma pigmentosum D correlate with response to platinum-based chemotherapy in the patients with advanced epithelial ovarian cancer. Int J Gynecol Cancer. 2008; 18:1007-1012. [PubMed: 18081788] 
214. Shahzad MM, Lopez-Berestein G, Sood AK. Novel strategies for reversing platinum resistance. Drug Resist Updat. 2009; 12:148-152. [PubMed: 19805003]

215. Aletti GD, Gostout BS, Podratz KC, Cliby WA. Ovarian cancer surgical resectability: relative impact of disease, patient status, and surgeon. Gynecol Oncol. 2006; 100:33-37. [PubMed: 16153692]

216. Fader AN, Rose PG. Role of surgery in ovarian carcinoma. J Clin Oncol. 2007; 25:2873-2883. [PubMed: 17617518]

217. Swann JB, Smyth MJ. Immune surveillance of tumors. J Clin Invest. 2007; 117:1137-1146. [PubMed: 17476343]

218. Zitvogel L, Tesniere A, Kroemer G. Cancer despite immunosurveillance: immunoselection and immunosubversion. Nat Rev Immunol. 2006; 6:715-727. [PubMed: 16977338]

219. Zhang L, Conejo-Garcia JR, Katsaros D, et al. Intratumoral T cells, recurrence, and survival in epithelial ovarian cancer. N Engl J Med. 2003; 348:203-213. [PubMed: 12529460]

220. Han LY, Fletcher MS, Urbauer DL, et al. HLA class I antigen processing machinery component expression and intratumoral T-Cell infiltrate as independent prognostic markers in ovarian carcinoma. Clin Cancer Res. 2008; 14:3372-3379. [PubMed: 18519766]

221. Zang X, Sullivan PS, Soslow RA, et al. Tumor associated endothelial expression of B7-H3 predicts survival in ovarian carcinomas. Mod Pathol. 23:1104-1112. [PubMed: 20495537]

222. Lee RC, Feinbaum RL, Ambros V. The C. elegans heterochronic gene lin-4 encodes small RNAs with antisense complementarity to lin-14. Cell. 1993; 75:843-854. [PubMed: 8252621]

223. Bartel DP. MicroRNAs: genomics, biogenesis, mechanism, and function. Cell. 2004; 116:281297. [PubMed: 14744438]

224. He L, Hannon GJ. MicroRNAs: small RNAs with a big role in gene regulation. Nat Rev Genet. 2004; 5:522-531. [PubMed: 15211354]

225. Ambros V. microRNAs: tiny regulators with great potential. Cell. 2001; 107:823-826. [PubMed: 11779458]

226. van Jaarsveld MT, Helleman J, Berns EM, Wiemer EA. MicroRNAs in ovarian cancer biology and therapy resistance. Int J Biochem Cell Biol. 42:1282-1290. [PubMed: 20083225]

227. Kumar MS, Lu J, Mercer KL, Golub TR, Jacks T. Impaired microRNA processing enhances cellular transformation and tumorigenesis. Nat Genet. 2007; 39:673-677. [PubMed: 17401365]

228. Calin GA, Croce CM. MicroRNA-cancer connection: the beginning of a new tale. Cancer Res. 2006; 66:7390-7394. [PubMed: 16885332]

229. Hu Y, Correa AM, Hoque A, et al. Prognostic significance of differentially expressed miRNAs in esophageal cancer. Int J Cancer. 128:132-143. [PubMed: 20309880]

230. Zhang L, Huang J, Yang N, et al. microRNAs exhibit high frequency genomic alterations in human cancer. Proc Natl Acad Sci U S A. 2006; 103:9136-9141. [PubMed: 16754881]

231. Yang H, Kong W, He L, et al. MicroRNA expression profiling in human ovarian cancer: miR-214 induces cell survival and cisplatin resistance by targeting PTEN. Cancer Res. 2008; 68:425-433. [PubMed: 18199536]

232. Nam EJ, Yoon H, Kim SW, et al. MicroRNA expression profiles in serous ovarian carcinoma. Clin Cancer Res. 2008; 14:2690-2695. [PubMed: 18451233]

233. Kim VN. MicroRNA biogenesis: coordinated cropping and dicing. Nat Rev Mol Cell Biol. 2005; 6:376-385. [PubMed: 15852042]

234. Croce CM. Causes and consequences of microRNA dysregulation in cancer. Nat Rev Genet. 2009; 10:704-714. [PubMed: 19763153]

235. Medina PP, Slack FJ. microRNAs and cancer: an overview. Cell Cycle. 2008; 7:2485-2492. [PubMed: 18719380]

236. Negrini M, Nicoloso MS, Calin GA. MicroRNAs and cancer--new paradigms in molecular oncology. Curr Opin Cell Biol. 2009; 21:470-479. [PubMed: 19411171]

237. Shah PP, Hutchinson LE, Kakar SS. Emerging role of microRNAs in diagnosis and treatment of various diseases including ovarian cancer. J Ovarian Res. 2009; 2:11. [PubMed: 19712461]

238. Merritt WM, Lin YG, Han LY, et al. Dicer, Drosha, and outcomes in patients with ovarian cancer. N Engl J Med. 2008; 359:2641-2650. [PubMed: 19092150] 
239. Chiosea S, Jelezcova E, Chandran U, et al. Up-regulation of dicer, a component of the MicroRNA machinery, in prostate adenocarcinoma. Am J Pathol. 2006; 169:1812-1820. [PubMed: 17071602]

240. Faggad A, Budczies J, Tchernitsa O, et al. Prognostic significance of Dicer expression in ovarian cancer-link to global microRNA changes and oestrogen receptor expression. J Pathol. 220:382391. [PubMed: 19960504]

241. Wu JF, Shen W, Liu NZ, et al. Down-regulation of Dicer in hepatocellular carcinoma. Med Oncol.

242. Martin MG, Payton JE, Link DC. Dicer and outcomes in patients with acute myeloid leukemia (AML). Leuk Res. 2009; 33:e127. [PubMed: 19278725]

243. Suzuki HI, Yamagata K, Sugimoto K, Iwamoto T, Kato S, Miyazono K. Modulation of microRNA processing by p53. Nature. 2009; 460:529-533. [PubMed: 19626115]

244. Stroun M, Maurice P, Vasioukhin V, et al. The origin and mechanism of circulating DNA. Ann N Y Acad Sci. 2000; 906:161-168. [PubMed: 10818614]

245. Anker P, Mulcahy H, Chen XQ, Stroun M. Detection of circulating tumour DNA in the blood (plasma/serum) of cancer patients. Cancer Metastasis Rev. 1999; 18:65-73. [PubMed: 10505546]

246. Mandel P, Metais P. [Not Available.]. C R Seances Soc Biol Fil. 1948; 142:241-243. [PubMed: 18875018]

247. Fournie GJ, Courtin JP, Laval F, et al. Plasma DNA as a marker of cancerous cell death. Investigations in patients suffering from lung cancer and in nude mice bearing human tumours. Cancer Lett. 1995; 91:221-227. [PubMed: 7767913]

248. Holdenrieder S, Stieber P, Forg T, et al. Apoptosis in serum of patients with solid tumours. Anticancer Res. 1999; 19:2721-2724. [PubMed: 10470228]

249. Stroun M, Anker P, Lyautey J, Lederrey C, Maurice PA. Isolation and characterization of DNA from the plasma of cancer patients. Eur J Cancer Clin Oncol. 1987; 23:707-712. [PubMed: 3653190]

250. Chen X, Bonnefoi H, Diebold-Berger S, et al. Detecting tumor-related alterations in plasma or serum DNA of patients diagnosed with breast cancer. Clin Cancer Res. 1999; 5:2297-2303. [PubMed: 10499596]

251. Nawroz H, Koch W, Anker P, Stroun M, Sidransky D. Microsatellite alterations in serum DNA of head and neck cancer patients. Nat Med. 1996; 2:1035-1037. [PubMed: 8782464]

252. Fiegl H, Millinger S, Mueller-Holzner E, et al. Circulating tumor-specific DNA: a marker for monitoring efficacy of adjuvant therapy in cancer patients. Cancer Res. 2005; 65:1141-1145. [PubMed: 15734995]

253. Kamat AA, Bischoff FZ, Dang D, et al. Circulating cell-free DNA: a novel biomarker for response to therapy in ovarian carcinoma. Cancer Biol Ther. 2006; 5:1369-1374. [PubMed: 16969071]

254. Wei WI, Yuen AP, Ng RW, Ho WK, Kwong DL, Sham JS. Quantitative analysis of plasma cellfree Epstein-Barr virus DNA in nasopharyngeal carcinoma after salvage nasopharyngectomy: a prospective study. Head Neck. 2004; 26:878-883. [PubMed: 15390201]

255. Gautschi O, Bigosch C, Huegli B, et al. Circulating deoxyribonucleic Acid as prognostic marker in non-small-cell lung cancer patients undergoing chemotherapy. J Clin Oncol. 2004; 22:41574164. [PubMed: 15483026]

256. Leung SF, Chan AT, Zee B, et al. Pretherapy quantitative measurement of circulating EpsteinBarr virus DNA is predictive of posttherapy distant failure in patients with early-stage nasopharyngeal carcinoma of undifferentiated type. Cancer. 2003; 98:288-291. [PubMed: 12872347]

257. Zachariah RR, Schmid S, Buerki N, Radpour R, Holzgreve W, Zhong X. Levels of circulating cell-free nuclear and mitochondrial DNA in benign and malignant ovarian tumors. Obstet Gynecol. 2008; 112:843-850. [PubMed: 18827127]

258. Moore RG, Brown AK, Miller MC, et al. The use of multiple novel tumor biomarkers for the detection of ovarian carcinoma in patients with a pelvic mass. Gynecol Oncol. 2008; 108:402408. [PubMed: 18061248] 
259. Lu KH, Patterson AP, Wang L, et al. Selection of potential markers for epithelial ovarian cancer with gene expression arrays and recursive descent partition analysis. Clin Cancer Res. 2004; 10:3291-3300. [PubMed: 15161682]

260. McIntosh MW, Drescher C, Karlan B, et al. Combining CA 125 and SMR serum markers for diagnosis and early detection of ovarian carcinoma. Gynecol Oncol. 2004; 95:9-15. [PubMed: 15385104]

261. Jacobs IJ, Rivera H, Oram DH, Bast RC Jr. Differential diagnosis of ovarian cancer with tumour markers CA 125, CA 15-3 and TAG 72.3. Br J Obstet Gynaecol. 1993; 100:1120-1124. [PubMed: 8297846]

262. Li C, Wong WH. Model-based analysis of oligonucleotide arrays: expression index computation and outlier detection. Proc Natl Acad Sci U S A. 2001; 98:31-36. [PubMed: 11134512]

263. Chau CH, Rixe O, McLeod H, Figg WD. Validation of analytic methods for biomarkers used in drug development. Clin Cancer Res. 2008; 14:5967-5976. [PubMed: 18829475]

264. Hogdall E. Cancer antigen 125 and prognosis. Curr Opin Obstet Gynecol. 2008; 20:4-8. [PubMed: 18196998]

265. Altman DG, Lyman GH. Methodological challenges in the evaluation of prognostic factors in breast cancer. Breast Cancer Res Treat. 1998; 52:289-303. [PubMed: 10066088]

266. Hayes DF, Bast RC, Desch CE, et al. Tumor marker utility grading system: a framework to evaluate clinical utility of tumor markers. J Natl Cancer Inst. 1996; 88:1456-1466. [PubMed: 8841020]

267. McShane LM, Altman DG, Sauerbrei W, Taube SE, Gion M, Clark GM. REporting recommendations for tumor MARKer prognostic studies (REMARK). Nat Clin Pract Oncol. 2005; 2:416-422. [PubMed: 16130938]

268. Cheng WF, Huang CY, Chang MC, et al. High mesothelin correlates with chemoresistance and poor survival in epithelial ovarian carcinoma. Br J Cancer. 2009; 100:1144-1153. [PubMed: 19293794]

269. Katz EM, Kattan MW. How to judge a tumor marker. Nat Clin Pract Oncol. 2005; 2:482-483. [PubMed: 16205748]

270. Liotta LA, Petricoin EF. Mass spectrometry-based protein biomarker discovery: solving the remaining challenges to reach the promise of clinical benefit. Clin Chem. 56:1641-1642. [PubMed: 20660141]

271. Khleif SN, Doroshow JH, Hait WN. AACR-FDA-NCI Cancer Biomarkers Collaborative consensus report: advancing the use of biomarkers in cancer drug development. Clin Cancer Res. 16:3299-3318. [PubMed: 20501613]

272. Abdel-Azeez HA, Labib HA, Sharaf SM, Refai AN. HE4 and mesothelin: novel biomarkers of ovarian carcinoma in patients with pelvic masses. Asian Pac J Cancer Prev. 11:111-116. [PubMed: 20593939]

273. Huang CY, Cheng WF, Lee CN, et al. Serum mesothelin in epithelial ovarian carcinoma: a new screening marker and prognostic factor. Anticancer Res. 2006; 26:4721-4728. [PubMed: 17214332]

274. Chambers SK, Kacinski BM, Ivins CM, Carcangiu ML. Overexpression of epithelial macrophage colony-stimulating factor (CSF-1) and CSF-1 receptor: a poor prognostic factor in epithelial ovarian cancer, contrasted with a protective effect of stromal CSF-1. Clin Cancer Res. 1997; 3:999-1007. [PubMed: 9815777]

275. Bao LH, Sakaguchi H, Fujimoto J, Tamaya T. Osteopontin in metastatic lesions as a prognostic marker in ovarian cancers. J Biomed Sci. 2007; 14:373-381. [PubMed: 17219251]

276. White NM, Mathews M, Yousef GM, et al. Human kallikrein related peptidases 6 and 13 in combination withCA125 is a more sensitive test for ovarian cancer than CA125 alone. Cancer Biomark. 2009; 5:279-287. [PubMed: 20037204]

277. Matsuzaki H, Kobayashi H, Yagyu T, et al. Plasma bikunin as a favorable prognostic factor in ovarian cancer. J Clin Oncol. 2005; 23:1463-1472. [PubMed: 15735122]

278. Hefler LA, Zeillinger R, Grimm C, et al. Preoperative serum vascular endothelial growth factor as a prognostic parameter in ovarian cancer. Gynecol Oncol. 2006; 103:512-517. [PubMed: 16750560] 
279. Rudlowski C, Pickart AK, Fuhljahn C, et al. Prognostic significance of vascular endothelial growth factor expression in ovarian cancer patients: a long-term follow-up. Int J Gynecol Cancer. 2006; 16(Suppl 1):183-189. [PubMed: 16515588]

280. Polterauer S, Grimm C, Mustea A, et al. Vascular endothelial growth factor gene polymorphisms in ovarian cancer. Gynecol Oncol. 2007; 105:385-389. [PubMed: 17289129]

281. Birrer MJ, Johnson ME, Hao K, et al. Whole genome oligonucleotide-based array comparative genomic hybridization analysis identified fibroblast growth factor 1 as a prognostic marker for advanced-stage serous ovarian adenocarcinomas. J Clin Oncol. 2007; 25:2281-2287. [PubMed: 17538174]

282. Li H, Cai KQ, Godwin AK, Zhang R. Enhancer of zeste homolog 2 (EZH2) promotes the proliferation and invasion of epithelial ovarian cancer cells. Mol Cancer Res.

283. Kleinberg L, Holth A, Trope CG, Reich R, Davidson B. Claudin upregulation in ovarian carcinoma effusions is associated with poor survival. Hum Pathol. 2008; 39:747-757. [PubMed: 18439941]

284. Lin CK, Chao TK, Yu CP, Yu MH, Jin JS. The expression of six biomarkers in the four most common ovarian cancers: correlation with clinicopathological parameters. APMIS. 2009; 117:162-175. [PubMed: 19245589]

285. Steffensen KD, Waldstrom M, Jeppesen U, Jakobsen E, Brandslund I, Jakobsen A. The prognostic importance of cyclooxygenase 2 and HER2 expression in epithelial ovarian cancer. Int J Gynecol Cancer. 2007; 17:798-807. [PubMed: 17309668]

286. Rubin SC, Finstad CL, Wong GY, Almadrones L, Plante M, Lloyd KO. Prognostic significance of HER-2/neu expression in advanced epithelial ovarian cancer: a multivariate analysis. Am J Obstet Gynecol. 1993; 168:162-169. [PubMed: 8093588]

287. Anderson KS, Wong J, Vitonis A, et al. p53 autoantibodies as potential detection and prognostic biomarkers in serous ovarian cancer. Cancer Epidemiol Biomarkers Prev. 19:859-868. [PubMed: 20200435]

288. Hogdall EV, Hogdall CK, Blaakaer J, et al. P53 autoantibodies in sera from Danish ovarian cancer patients and their correlation with clinical data and prognosis. APMIS. 2002; 110:545553. [PubMed: 12390412]

289. Barbieri F, Lorenzi P, Ragni N, et al. Overexpression of cyclin D1 is associated with poor survival in epithelial ovarian cancer. Oncology. 2004; 66:310-315. [PubMed: 15218299]

290. Scheil-Bertram S, Tylus-Schaaf P, du Bois A, et al. Excision repair cross-complementation group 1 protein overexpression as a predictor of poor survival for high-grade serous ovarian adenocarcinoma. Gynecol Oncol. 119:325-331. [PubMed: 20728204]

291. Lin M, Yin N, Murphy B, et al. Immune cell-derived c3 is required for autoimmune diabetes induced by multiple low doses of streptozotocin. Diabetes. 59:2247-2252. [PubMed: 20584999]

292. Lin F, Lin K, Xie X, Zhou C. Increased ERCC1 protein expression is associated with suboptimal debulking in advanced epithelial ovarian cancer. Anticancer Res. 30:2447-2452. [PubMed: 20651406]

293. Konstantinopoulos PA, Spentzos D, Karlan BY, et al. Gene expression profile of BRCAness that correlates with responsiveness to chemotherapy and with outcome in patients with epithelial ovarian cancer. J Clin Oncol. 28:3555-3561. [PubMed: 20547991]

294. Cvelbar M, Ursic-Vrscaj M, Rakar S. Risk factors and prognostic factors in patients with double primary cancer: epithelial ovarian cancer and breast cancer. Eur J Gynaecol Oncol. 2005; 26:59_ 63. [PubMed: 15755003]

295. Penson RT, Kronish K, Duan Z, et al. Cytokines IL-1beta, IL-2, IL-6, IL-8, MCP-1, GM-CSF and TNFalpha in patients with epithelial ovarian cancer and their relationship to treatment with paclitaxel. Int J Gynecol Cancer. 2000; 10:33-41. [PubMed: 11240649]

296. Lambeck AJ, Crijns AP, Leffers N, et al. Serum cytokine profiling as a diagnostic and prognostic tool in ovarian cancer: a potential role for interleukin 7. Clin Cancer Res. 2007; 13:2385-2391. [PubMed: 17438097]

297. Zeimet AG, Widschwendter M, Knabbe C, et al. Ascitic interleukin-12 is an independent prognostic factor in ovarian cancer. J Clin Oncol. 1998; 16:1861-1868. [PubMed: 9586902] 
298. Cheng X, Jiang R, Li ZT, et al. The role of secondary cytoreductive surgery for recurrent mucinous epithelial ovarian cancer (mEOC). Eur J Surg Oncol. 2009; 35:1105-1108. [PubMed: 19443175]

299. Simon I, Katsaros D, Rigault de la Longrais I, et al. B7-H4 is over-expressed in early-stage ovarian cancer and is independent of CA125 expression. Gynecol Oncol. 2007; 106:334-341. [PubMed: 17498784]

300. Marth C, Fiegl H, Zeimet AG, et al. Interferon-gamma expression is an independent prognostic factor in ovarian cancer. Am J Obstet Gynecol. 2004; 191:1598-1605. [PubMed: 15547530]

301. Duncan TJ, Rolland P, Deen S, et al. Loss of IFN gamma receptor is an independent prognostic factor in ovarian cancer. Clin Cancer Res. 2007; 13:4139-4145. [PubMed: 17634541]

302. Hu X, Macdonald DM, Huettner PC, et al. A miR-200 microRNA cluster as prognostic marker in advanced ovarian cancer. Gynecol Oncol. 2009; 114:457-464. [PubMed: 19501389] 


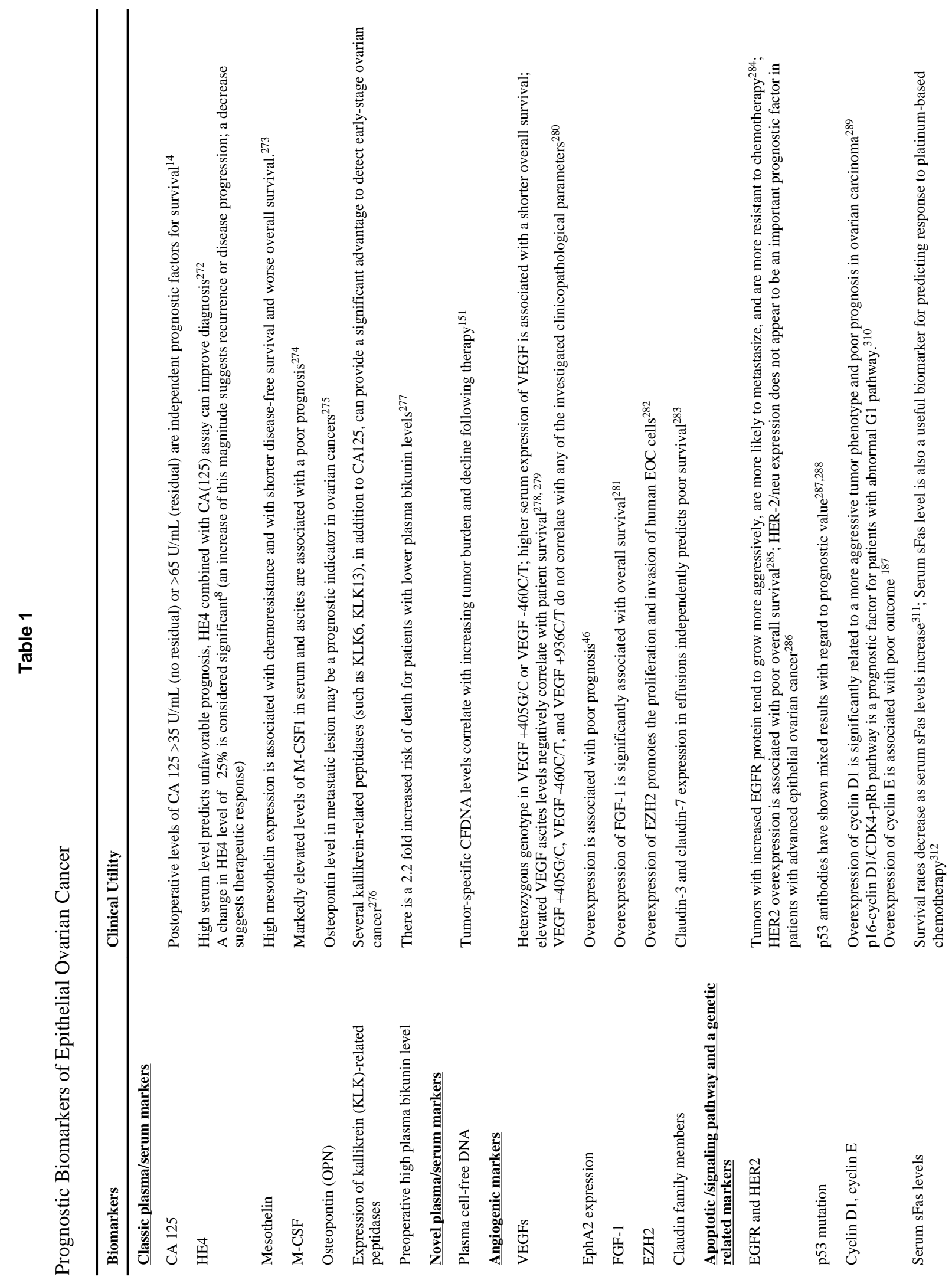




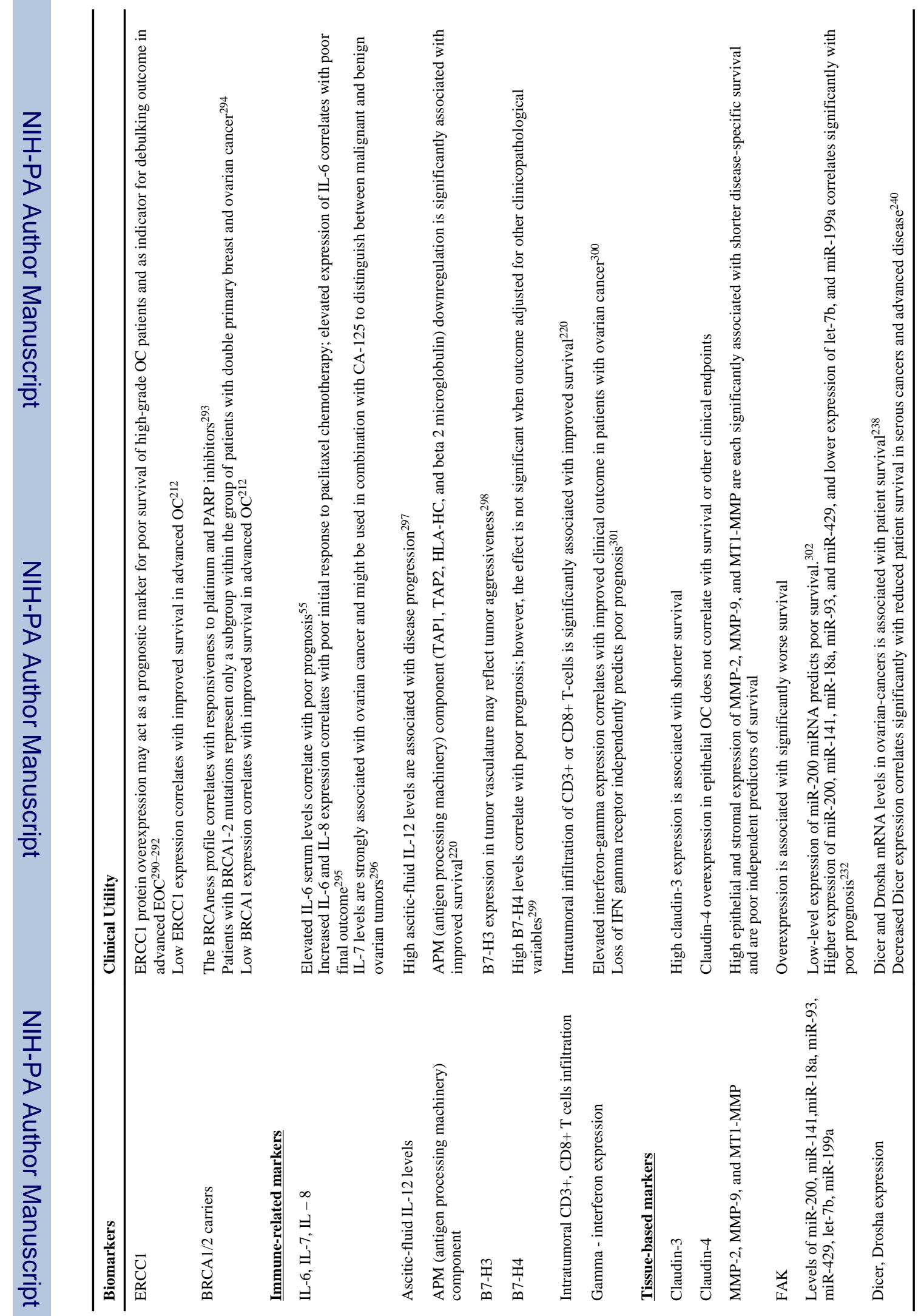

